\title{
Article
}

\section{Gifting, Exchange and Reciprocity in Thai Annual Reports: Towards a Buddhist Relational Theory of Thai Accounting Practice}

Constable, Philip and Kuasirikun, Nooch

Available at http://clok.uclan.ac.uk/20590/

Constable, Philip ORCID: 0000-0001-9234-1408 and Kuasirikun, Nooch (2018) Gifting, Exchange and Reciprocity in Thai Annual Reports: Towards a Buddhist Relational Theory of Thai Accounting Practice. Critical Perspectives On Accounting, 54 . pp. 1-26. ISSN 1045-2354

It is advisable to refer to the publisher's version if you intend to cite from the work. http://dx.doi.org/10.1016/j.cpa.2017.08.002

For more information about UCLan's research in this area go to http://www.uclan.ac.uk/researchgroups/ and search for <name of research Group>.

For information about Research generally at UCLan please go to http://www.uclan.ac.uk/research/

All outputs in CLoK are protected by Intellectual Property Rights law, including Copyright law. Copyright, IPR and Moral Rights for the works on this site are retained by the individual authors and/or other copyright owners. Terms and conditions for use of this material are defined in the policies page. 


\title{
Gifting, exchange and reciprocity in Thai annual reports: Towards a Buddhist relational theory of Thai accounting practice
}

\author{
Philip Constable Nooch Kuasirikun
}

\begin{abstract}
A B S T R A C T
This paper analyses the inter-relationship of human agency and socio-economic structure in the determination of Thai accounting. It demonstrates that determination of accounting practice lies neither in the individual agency of human practice, nor in the forces of socioeconomic structure per se, but rather in patterns of relational practice. Drawing on the theoretical framework of Mauss (1925) to analyse accounting practice as revealed in Thai company annual reports, this paper elaborates a Buddhist relational theory of accounting practice that focuses on the importance of patterns of practice generated by gifting, exchange and reciprocity. It studies the ways that accounting as evidenced in the relational practices of Thai annual reports creates patterns of corporate, societal and state identity in late 20th and early 21 st-century Thailand. The article also relates this Thai Buddhist conceptualisation of practice to other theoretical approaches, particularly Foucault, Giddens and Latour, which accounting historians have adapted to express the interaction of human and structural agency in practice. In doing so, the paper seeks to highlight some of the limitations in such accounting theorisation and emphasise the importance of a focus on normative patterns of relational practice as an explanation of accounting formation.
\end{abstract}

\section{Introduction}

Since Anthony Hopwood's seminal article (1983) arguing for the study of accounting in terms of its context, it has become axiomatic that accounting cannot be fully understood without reference to its human agents and economic, socio-cultural and political environment. Definition of causal factors which determine change in this context has varied widely in the critical accounting literature, but in broad theoretical terms Emirbayer (1997) provides a useful methodological classification between substantialist and relational explanations, namely whether to conceive of societal context in foremost terms of the agency of human actors and/or collective structures, or rather to lay primary importance on their dynamic unfolding relations in practice. Emirbayer (1997) suggests that substantialist interpretations place emphasis on 'self-action', that is individuals and structures acting under their own will or power independently of others, or on 'inter-action', whereby action takes place between individuals and/or structures, but the individuals and/or structures remain unchanging, each 
independent of the existence of the others. In contrast to both varieties of substantialism is 'trans-action' whereby individuals and structures derive their changing significance and identity from their functional role in dynamic relational practice, rather than the constituent elements being determinant per se or having independent existence beyond such relations. Emirbayer (1997) argues that human actors, collective structures and states, all gain their changing meaning and shifting identity through the dynamic and unfolding relational practice that is predicated of them. In terms of Hopwood's agenda (1983) of studying accounting in its context, it is argued below that critical accounting needs to focus on these transactional dynamics or patterns of relational practices rather than primarily on structures and human agents.

As this paper first shows, critical accounting researchers have demonstrated the different ways and degrees in which a trans-actional or relational sociology of accounting practice has been used in the critical accounting literature. However there often appears to be a need, especially in the accounting literature focused on Foucault, Giddens and Latour, for greater recognition of how such relational practices are invested with normative values and translate into normative patterns of practice that in turn condition future practice. With this purpose in mind, this paper, secondly, draws attention to the continuing importance of Mauss's (1925) work with its emphasis on the socio-economic determinacy of normative relational practice in the form of gifting, exchange and reciprocity in the south-east Asian and Asia-Pacific context. The paper seeks to adapt the insights of Mauss (1925) to the study of Thai corporate reports from the late 1990s to 2010s as a means of understanding how Thai actors, systems and discourses are ultimately shaped collectively in dynamic normative patterns of relational practice. In this context, the paper elaborates a theory of Buddhist relational practice as evidenced in Thai annual reports (1990s-2010s) to demonstrate how the causal force in relational practice is in part focused around normative purpose. It is argued that, in addition to reporting in terms of International Accounting Standards, normative Buddhist relational practice determines the nature of accounting practice in Thailand.

Drawing on and developing Mauss's (1925) theorisation of gifting, exchange and reciprocity in a Buddhist form, the paper analyses three specific relational ways in which Thai Buddhist normative practice is reflected in and determines Thai annual reports and the business practices that they record. First, Thai annual reports are shown frequently to promote a Buddhist normative sense of mindfulness (sati) focused in practice in the 'gift of mindfulness' as a paradigm for business activity (in addition to aims of material profit-based exchange). This sense of gifting of mindfulness provides a Thai normative framework for the financial information in terms of International Accounting Standards in Thai company reports. Secondly, the paper analyses the importance of giving (tamtan) and receiving merit in return (tambun) in Thai company reports as another means of giving expression in practice to normative Thai Buddhist values. Such gifting and merit creation find expression not only in relational practice involving employees, clients and corporate stakeholders, but also the broader community in which companies in Thailand operate. Finally, the paper analyses how such micro-relational gifting practices in Thai companies form part of normative gifting patterns in material and discursive terms which trans-actionally associate companies, socio-economic groups, sangha (monkhood) and monarchy as inter-related components of the Thai state. This paper discusses these three forms of relational practice as revealed in Thai annual reports and seeks to show how they define a normative sense of self, corporate identity and consensual order for Thai society in terms of a Buddhist theory of relational practice.

\section{A relational sociology of accounting practice}

A relational sociology of accounting practice has long been at least an implicit conceptual framework in the theorisation of accounting practice through use of the works of Gramsci, Foucault, Giddens and Latour. Foucault for example elaborated the relational sociology that Gramsci (1977) had posited between super-structural ideologies and material forces of the economic base by further re-focusing on discursive practice (Foucault, 1965,1975, 1977a, pp. 195-228; see also Dreyfus \& Rabinow, 1982; Grey, 1994; Poster, 1984; Smart, 1983; 1988). As Smart (1986, p. 162) has indicated, Foucault (1977a, 1981) through his focus on practice and discursive formations of practice sought to provide non-reductionist descriptions of power relations by de-centring the role of individuals or collective actors, classes or state, which Marx (1975c, p. 244) and Gramsci (1971, pp. 161, 366; 1977, pp. 34-35) had perceived to exert power as a result of control over the means of production and negotiation of consensual hegemony. ${ }^{1}$ Foucault's genealogical methodology (Foucault, 1977a, p. 29; 1981, p. 94) analysed the individual as an articulation of the relations of power that are immanent and fluctuating in his/her micro-statements and practices. It also charted the formation of a plurality of disparate but accumulative micro-statements/practices over time into genealogies (see Miller \& Napier's (1993) British accounting genealogy) and the transformation of genealogies in disjunctive trajectories to unforeseeable ends (see Hoskin \& Macve's $(1986,1988)$ genealogy of accountability). Foucault particularly emphasised in his later work the impact of such formations of accumulative practice in creating self-disciplining 'subjects' (see Kearins \& Hooper (2002) on Maori land expropriation, or Miller \& O'Leary (1987) on discourses of national efficiency). This self-disciplinary practice is seen to replicate into institutional subjection where organised practices, like accounting. contribute to the construction of disciplinary regimes (see the 18th-century Spanish Royal Tobacco Factory (Carmona,

\footnotetext{
1 Gramsci's relational sociology drew on Marx's early work (Marx, 1978, p. 247; Marx, 1975a, 1975b) which argued that 'society does not consist of individuals, but expresses the sum of inter-relations, the relations within which these individuals stand'. Hence Gramsci (1977, pp. 34-35) indicated that the individuals, but expresses the sum of inter-relations, the relations within which these individ a hegemonic class is preferably articulated through relational and consensual practice with other groups within and across classes (Anderson, 1976; Boggs, 1978; Joll, 1977; Ransome, 1992).
} 
Ezzamel \& Gutierrez, 1997, 2002), the 19th-century New Lanark Mill in Britain (Walsh \& Stewart, 1993), late 20th-century British industry (Knights \& Collison, 1987), medieval confessional/accounting practice in Italian religious institutions (Quattrone, 2004) and Ciceronian rhetoric as a template for double-entry bookkeeping in 16th-17th-century Italy (Aho, 1985, 2005). As these accounting studies reveal in terms of Emirbayer's (1997) sociology of relational practice, a power-based truth-claim and ultimately a hegemonic 'regime of truth' (Foucault, 1980, p. 133) are constructed and constantly re-shaped by evolving 'trans-actional' sequences of discursive and material practices, rather than by the 'self-action' or 'inter-action' of individual and collective structural agencies.

A sociology of relational practice is also an essential element of Giddens' structuration theory $(1979,1984)$ as a means of resolving a dichotomy between the determinacy of structural forces and the agency of individual actors. Roberts and Scapens (1985) and Macintosh (1994), for example, have applied what Giddens (1979, p.5) terms a 'duality of structure' to management accounting, whereby internalised 'virtual structures' of signification (communication of meaning), legitimation (sanction according to norms) and domination (exercise of transformative or subjective power) inter-relate through the memory of collective actors to form a virtual medium upon which they draw to enable engagement in successive accounting practice (Giddens, 1979, pp. 81-83). As Macintosh and Scapens (1990, 1991), Buhr (2002), Conrad (2005) and others have demonstrated, accounting actors and collective structures are recursively determined by the deployment of such virtual structures which inter-relate actor and structure at the instant of accounting practice itself (Giddens, 1979, pp. 64, 8894,$104 ; 1984$, p. $377 ; 1993$, pp. 84, 90-91). ${ }^{2}$ Macintosh and Scapens (1990) also elaborated how power relations arise through relational practice in Giddens' terms of a 'dialectic of control'. In their accounting case study, the University of Wisconsin resisted a revised accounting scheme required by the State of Wisconsin as a result of change in the latter's signification structure for public funding from a notion of university autonomy in expenditure (with a legitimation norm of efficiency) in the 1970s, to a signification structure focused on state needs (with a legitimation norm of economic recovery) in the 1980 s. $^{3}$ Both in terms of a 'duality of structure' and a 'dialectic of control', the use of structuration theory in accounting emphasises Emirbayer's (1997) point that the - gency of actors and collective entities is constructed in the dynamic of relational practice that is predicated of them.

Studies of accounting practice using Latour $(1987,1996)$ have also used a relational sociology of accounting practice. Justesen and Mouritsen (2011) have argued that much of the accounting literature with its focus on Latour (1987) has centred on how accounting is a contingent process in which heterogenous groups of people, inscriptions and technologies are temporarily associated at instants in time in on-going network constructions (see Huikku \& Lukka, 2016; Mackenzie, 2009; Miller, 1990, 1991; Robson, 1991, 1992). In particular, this accounting literature focuses on how 'translation', namely 'displacement, drift, invention, mediation (in) the creation of a link' within a network (Latour, 1999, p. 179), generates new definitions of meaning and action, often out of multiple causes and with unexpected consequences (see Briers \& Chua, 2001; Chua, 1995; Christensen \& Skaerbaek, 2010; Dechow \& Mouritsen, 2005; Gendron, Cooper, \& Townley, 2007; Jores \& Dugdale, 2002; Llewellyn \& Northcott, 2005; Miller \& O'Leary, 2007; Mouritsen, Hansen, \& Hansen, 2009; Preston, Cooper, \& Coombs, 1992). Thus, for example, adapting Latour, Quattrone (2009) has suggested that accounting essemplare of 15 th/16thcentury Italy created actor-networks between authors, readers, texts and material objects, which enabled a multiplicity of re-presentations and therefore allowed users to develop a calculative ability to extend the possibilities of organising knowledge in topical ways and modify dominant discourses through appropriated but localised networks of practice. Similarly, Ahrens and Chapman $(2002,2004,2005,2007)$ have drawn on Schatzki's (2002) theory of arrays of activity and Latour's $(1987,1996)$ actor-network theory to study the ways in which a relational network of employees and non-human or technical agents in a large British restaurant chain actively and collectively reconstituted management control and enabled its re-shaping by arrays of local practice. Both studies using Latour seek to demonstrate how a discourse of rules, procedures and standards shares intentionality with alternative judgements derived through a heterogenous network of human and technical actants in pursuit of the modification of dominant norms in particular instances of practice. Actor-network theory thereby in relational terms moves beyond methodologies that focus agency in what Emirbayer (1997) termed the 'selfaction' or 'inter-action' of powerful individuals, as well as governability structures and hegemonic discourses.

In respect of such relational sociologies of accounting practice, one important limitation however lies in explaining how governability might not only be seen to be a result of instrumental networks of accumulating and evolving practice, but might also be driven by normative judgement and collective value consensus. Foucault's (1977b; 1981) use of a genealogical methodology to concentrate on the development and re-invention of practice from the viewpoint of disciplinary power has led some of the Foucault-based accounting literature to strip away so much normative intentionality in practice that emphasis at times comes to rest on a 'regime of truth' based on pancratic practices of subjection at the expense of a

\footnotetext{
${ }^{2}$ For example, Capps, Hopper, Mouritsen, Cooper and Lowe (1989) on the British National Coal Board 1982-84; Macintosh and Scapens (1990, 1991) on the University of Wisconsin, General Motors and Department of Defence; Lawrence, Alam, Northcott, and Lowe (1997) on the New Zealand healthcare system; Buhr (2002) on Canadian paper companies Abitibi-Price and Avenor in the 1980s-1990s; Ahrens and Chapman (2002) on performance management in a UK restaurant chain; Conrad (2005) on British Gas; Tollington (2006) on FRS10 rule structuration; Moore (2013) on an Australian water business. For review articles, see Englund and Gerdin (2008, 2014), Englund, Gerdin and Burns (2011), Moore (2011).

${ }^{3}$ For case studies using a dialectic of control, see Conrad (2005) on British Gas, Tollington (2006) on FRS10, Manson, McCartney, and Sherer (2001) on audit automation; Macintosh (1995) on profit manipulation; Seal (2003) on local government budgeting; Scheytt, Soin, and Metz (2003) on accounting influence over regulatory decisions; Uddin and Tsamenyi (2005) on state-Ghana Food Distribution Corporations relations; Jack (2007) on farmer government, supermarket supply chain relationships.
} 
concomitant articulation of normative motivations for accounting practice, such as derived from value solidarity or moral consensus (see Carmona et al., 1997, 2002; Knights \& Collison, 1987; Walsh \& Stewart, 1993). Without normative motivation or collective value solidarity, it is difficult in the Foucault-oriented literature to demonstrate fully how localised practice evolves and translates into hegemonic forms other than by contingent accumulation of statement and practice.

Likewise, Boland $(1993,1996)$ has interrogated Giddens' 'circuits of reproduction', whereby situated practice recursively reproduces patterns or coalesces networks, rather than necessarily generates or is driven by value consensus (Giddens, 1984 , pp. 293-97). Cohen (1999, p. 97) too has suggested that Giddens' emphasis (1991, pp. 36-37) on individual motivation driven primarily by a need for the ontological security of routine practice can lead to under-statement of the normative intentions of social practice grounded in collective solidarity, moral consensus or democratic principles. Like Foucault, an emphasis on accumulation or circuits of practice can tend to marginalise normative intentionality in that practice. Stones (2005) has also suggested that Giddens' 'methodological bracketing' (1984, pp. 288-93) tends to counteract explanation of how relational practice connects different levels of (individual, institutional and societal) analysis, in particular in terms of Giddens' (individual) 'strategic conduct analysis' and 'institutional analysis'. Various accounting analyses have sought to overcome the limitations of such methodological bracketing by applying Stone's quadripartite cycle of strong structuration (2005, pp. 8486) and by using his distinction between 'agent conduct analysis' and 'agent context analysis' (2005, pp. 121-23) in association with 'position-practice relations' from Cohen (1989) (see Coad \& Glyptis, 2014; Coad \& Herbert, 2009; Coad, Jack, \& Kholeif, 2015, 2016; Feeney \& Price, 2016; Harris, Northcott, Elmassri, \& Huikku, 2016; Jack \& Kholeif, 2007, 2008; Makrygiannakis \& Jack, 2016). As Englund, Gerdin, and Burns (2011, p. 507) and Englund and Gerdin (2014, p.177) have suggested, strong structuration studies in accounting have thereby elaborated usefully on the ways day-to-day practices in accounting reproduce company/institutional structures (see Ahrens \& Chapman, 2002; Capps et al., 1989; Feeny \& Price 2016; Harris et al., 2016; Roberts, 1990), although few directly link these situated practices to the wider structures of society (see Macintosh \& Scarpins, 1990; Moore \& McPhail, 2016). Without greater emphasis on normative intentionality and consensual value motivation, it is however difficult, as Boland $(1993,1996)$ has in part indicated of Giddens (1984), to overcome methodological bracketing. Emphasis on instrumentalist analysis, which at best defines normative motivation in terms of sanction according to 'norms' and 'legitimation', undervalues the driving force of normative values and moral consensus in generating 'circuits of reproduction' and linking the different levels of social analysis revealed in strong structuration theory.

Similarly, as Whittle and Spicer (2008, pp. 612,616-17) have indicated, the ontological realism and network determinism of Latour's actor-network theory can also render it less well-equipped for pursuing critical normative accounts of an organisation in terms of challenges to the limits of its knowledge and structures of domination. The primary focus in many studies using Latour (1987) tends to be on the instrumentality of network formation and, as Huikku \& Lukka (2016, p. 249) have indicated, on the instrumentality of processes of 'fabrication' (Chua, 1995; Preston et al., 1992), 'fact-building' (Briers \& Chua, 2001; Chua, 1995), 'purifying' (Christensen \& Skaerback, 2010; Power, 1996), and especially 'translation' (Gendron et al., 2007; Miller, 1990; Mouritsen et al., 2009; Robson, 1991). Moreover, early studies like Preston et al. (1992) and Broomfield, Cooper, and Rea (1992) in their studies of NHS accounting in the 1980s established an emphasis in which network actants frequently appear guided more by instrumental negotiation of allegiances, persuasive power and even machination than by conflicting value motivations for accounting change. As multifarious actant networks generate the changing genealogy of an action in its evolution in new series or directions and build up into discursive and material formations, it can be difficult to identify fully the linking patterns of such developments in the absence of an emphasis on normative motivation or value consensus. In sum, an under-articulation of normative motivation and collective valueconsensus can result in an over-emphasis on instrumentality and power-based explanations in a relational sociology of practice and limit understanding of how routine accounting practice translates into patterns of governability.

\section{Mauss: Towards a Buddhist relational sociology of Thai accounting practice}

In respect of these limitations in sociologies of relational practice, Mauss's (1925) insights are significant. First, like Foucault, Giddens and Latour, Mauss's work demonstrates Emirbayer's point (1997) that socio-economic practice is not merely determined by the 'self-action' or 'inter-action' of singular individuals, collective structures or hegemonic discourses, but by the dynamic relational or 'trans-actional' practices of a multiplicity of agents, collective structures, and discursive variations. Secondly and importantly, however, Mauss's (1925) insights on gifting practice help exemplify how routine socioeconomic practice is invested with normative motivations that translate into patterns of practice and governability which are driven by collective normative judgements and value consensus. Such an emphasis on the importance of normative intentionality in practice was revealed in Mauss's debate with Malinowski. Malinowski (1922) had originally demonstrated that a sociology of relational practice in the form of gift-giving, exchange and reciprocity in the Trioband Islands in early 20th-century Papua New Guinea was a process by which economic and political leadership was asserted over an extensive archipelago. Where Malinowski (1922) emphasised relational gift-exchange between individuals for non-altruistic motives with an expectation of equivalent or greater political/economic return, Mauss (1925) however emphasised that giftexchange was not just between individuals for instrumental benefit, but between individuals as members of social collectives in the form of a functional service carried out from a sense of normative obligation to build and maintain the wider collective. Mauss stressed that gifts give rise to reciprocal exchange because a gift is a total prestation which is invested with the spiritual power, personal identity, history and honour of the giver in relation to the recipient. The giver does not 
merely gift a material object, but a part of him/herself with that object. Hence gifts are never completely separated from those who exchange them and this 'spirit of the gift' creates a relational impetus for return (Mauss, 1979). Because this concept of reciprocation of the gift creates a relationship over time, a social bond is established which continues until the future moment of return. Relational acts of giving and receiving thereby generate social collectivity. Giving creates and maintains social cohesion, while receiving accepts and consolidates that social unity because to reject a gift is to refuse a social relationship. Reciprocation of the gift demonstrates the honourable engagement of the initial recipient in the on-going promotion of the social collective. In elaboration of Durkheim's (1893/1984) understanding of social cohesion, Mauss (1925) indicated that social solidarity is created through the social bonds stimulated by relations of reciprocity as expressed in the practice of gift exchange. This paper demonstrates how such gifting and relations of reciprocity in late 20th and early 21 stcentury Thai annual reports generate similar normative patterns of solidarity in Thai society.

Levi-Strauss (1969) subsequently generalised Mauss's analysis in structuralist terms by arguing that social relations are based on structures of relational reciprocity of which the three main types of exchange are language, kinship and economic (exchange of words, brides and products). Other anthropological commentators, like Leach (1961) in his study of the Kachin system of matrimonial exchange in Burma, and Blau's (1967) theoretical sociology of exchange and power, perceived such relational exchanges as inherently requiring a balanced reciprocity, but often in different media, for example an increase in status, power and social authority that bride-givers received in return for matrimonial alliances. Sahlins (1972) also identified the importance of a balanced return in terms of three types of relational socio-economic reciprocity: namely generalised reciprocity, in which an unaccounted exchange of goods occurred with only a general expectation of some balanced return over time; symmetrical reciprocity in which a balanced return was expected within a specific time; and negative reciprocity in which both giver and receiver profited from the exchange. For Sahlins, generalised reciprocity, or what Mauss had classified as gifting, only tended to occur in integrated kinship groups and the more distant the recipient, the less balance there was and the greater the occurrence of symmetrical or negative reciprocity. More recently Weiner's (1992) critique of Malinowski's research on Trioband Island society has also developed Mauss's arguments on relational reciprocity and the spirit of the gift by further emphasising the inalienable nature of certain possessions. Weiner draws a distinction between moveable goods, which can be exchanged, and immoveable goods which attract gifts back to their source. She argued that, although moveable, certain lineage items were so closely associated with specific groups that they could never be alienated even when gifted to others and a (balanced) return was always required. As this anthropological literature has built out of Mauss (1925), it has emphasised the importance of the balanced reciprocity of gifts (be they in dissimilar material or non-material forms) and the inalienable spirit of certain gifts which always need return. This paper shows how the concept of balanced reciprocity of gifts is also a fundamental constituent of the normative dynamics of Thai annual reports and the patterns of business practice that they represent.

Unlike Mauss's focus (1925) on Melanesian, Polynesian and indigenous American societies, Hindu or Buddhist societies like India and Thailand respectively created a difficulty for Mauss's theory of balanced reciprocity of gifts. As Parry (1986) and Michaels (1997) have indicated, Hindu and Buddhist concepts of gifting (dana, or tamtan in Thai) seem to contradict Mauss's theorisation by emphasising that a gift should never be reciprocated. Ohnuma (2005, p. 106) has however indicated that the theory of dana in Hinduism and Buddhism is complemented by the law of kamma or merit creation which allows the elaboration of distinction between the seen or worldly (laukika) and unseen or transcendent (lokottara) fruits of gifting. Any gift which is materially reciprocated in this world has a seen profit and effect in creating social solidarity which belongs wholly to the ordinary socio-economic realm in line with barter, sale or purchase. The apparently unreciprocated gift however has no visible worldly fruit, but a transcendent return in the form of spiritual merit (punya, or bun in Thai). This paper argues that Thai annual reports operate in such Buddhist relational terms, whereby reciprocated gifting can be a means to material benefit for a company, but unreciprocated gifting is widely perceived to garner a transcendent return in terms of merit generation for company and wider Thai society.

Such analyses of the importance of balanced reciprocity have also been elaborated in terms of power and status relations. In similar ways to Sahlins's (1972) definition of generalised reciprocity, Weiner (1992) on the Trioband Islands and Schrauwers's (2004) study of the Toraja community in Indonesia associated the inalienable gift with the existence of certain kinship groups or landowning lineages for whom total prestation was a means of asserting socio-economic status and power. Similarly, in his study of the Moka exchange system of Papua New Guinea, Gregory (1982) argues that gifting aims to establish a relationship that asserts the authority of the politically-influential giver over recipients by placing the later in debt until the gift is reciprocated with interest (moka). A debt exactly re-paid would conclude the relationship, but the relationship would be maintained when a debt is re-paid with interest as a means of augmenting the prestige of the re-payer and placing the recipient/initial donor in debt. Sahlins (1963) in his study of how political systems are constructed out of status relationships also demonstrated in Melanesia and Polynesia how 'Big Men' emerged in politics through the ability of persuasion, of which gifting formed a part. Parry $(1980,1986)$ in his study of Benares funeral priests and Goodwin-Raheja (1988) in her study of ritual prestation in north India have further emphasised how a gift might be given to Hindu funeral priests or Hindu lower-castes with no wish for reciprocation in order to create dependency and inferiority because the gift contains a poison or impurity which was thereby removed from the donor. Seen in terms of power and status, reciprocated and unreciprocated gifting also constructs hierarchy and dominance within the socio-economic collective. This paper reveals how Thai annual reports use relations of reciprocity in terms of gifting and merit generation to construct status and power relations within Thai society. 
The interrelationship between market and non-market exchange is also very relevant in understanding the nature of gifting. Gregory (1982, p. 100) has argued that commodity exchange is an exchange of alienable items between people in a state of reciprocal independence that establishes a quantitative relationship between the items exchanged, while gift exchange is an exchange of inalienable items between people in a state of reciprocal dependence that creates a qualitative relationship between the trans-actors. Likewise Parry and Bloch (1989) have emphasised that the social reproduction of the lineage or family in rituals that require gifting are different from market exchange relations. In this context, Parry (1986, pp. 455-59) has, however, indicated that Mauss's interpretation of 'gift-exchange - in which persons and things (viz. the 'spirit of the gift'), interest and disinterest are merged - has become fractured, leaving gifts opposed to exchange, persons opposed to things, and interest to disinterest'. Ultimately the ideology of a disinterested gift has been counter-posed to the ideology of a purely interested exchange, whereas for Mauss gifting or total prestation was a hybrid relational exchange which intermixed gifts and loans as well as conflated persons and things with the aim of promoting social solidarity. Furthermore Thomas (1991) has analysed how items might move between domains or, in Thomas's words, become 'entangled objects' which can be singularised as unique gifts and commodified as goods for market exchange. Gift exchange is not therefore necessarily a discrete domain, but inter-relates with commodified forms of market exchange. Thai annual reports demonstrate this interrelatedness of gift exchange with market exchange in the way in which Thai accounting is determined not only by International Accounting Standards, but is also 'entangled' in Buddhist cultural perceptions of exchange and reciprocity which further decide what accounting, business practice and annual reports should be.

Overall, the aim of Mauss and his later commentators has been to explain socio-economic solidarities which are constructed through the normative relational bonds created by gift exchange practice. Likewise, it is argued in this paper that patterns of Thai corporate identity, social solidarity and political cohesion are formed normatively by the material and discursive bonds established through the Thai Buddhist relational practice of gifting and reciprocity as demonstrated in Thai annual reports. After a discussion of the paper's evidential base and research methodology in the following section 4 , section 4.1 demonstrates how Thai annual reports often promote a normative sense of corporate practice in terms of the 'gift of mindfulness' in business practice as a complement to material aims of profit-based exchange. Section 4.2 studies the importance of charitable giving (tamtan) and receiving merit in return (tambun) in the narratives of Thai company reports as another means of giving socio-economic expression in practice to normative Thai Buddhist values of mindfulness. Section 4.3 of the paper demonstrates how these two examples of Buddhist relational practice in sections 4.1 and 4.2 translate into patterns of practice that generate societal integration and governability based on normative consensus. It also shows how such practice leads to the elaboration of hierarchies of status and socio-economic competition within a social collective where gift exchange and market exchange are entangled. There are however limitations in Mauss's (1925) functional theorisation of the self and its agency when fully conceptualised in terms of a Buddhist theory of relational practice. The discussion in section 5 therefore outlines how a Buddhist theory of relational practice would express issues of self and collective agency in re-elaboration of Mauss (1925) and in contrast to the sociologies of relational practice in Foucault, Giddens and Latour.

\section{Evidence base and research methodology}

The period of this study ranges from 1998 to 2015, representing a period of Thai business recovery from the financial crisis of 1997 to the most current year of annual reports available when the survey was conducted. To some extent, the early years after 1997 represented a period of Thai focus on community and society in the wake of the socio-economic effects of the 1997 economic crisis, but the Buddhist cultural focus of Thai corporate reports ultimately extended well into and beyond the decade after 1997 by which time economic recovery had become established. An initial random sample analysis of 30 selected annual reports was piloted using both English and Thai versions of the annual reports. All the reports in the initial sample contained information on Buddhist cultural practice. The data in both initial and final samples was collated using a standardised content analysis sheet which highlighted different categories of disclosure, such as reference to Buddhist cultural practices, gifting and exchange, royal philanthropic institutions, socio-economic organisation, and monarchy. The

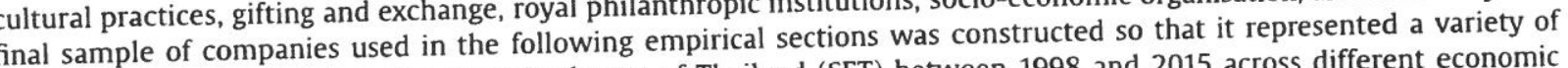
(he Stock Exchange of Thailand (SET) between 1998 and 2015 across different economic different companies listed on the Stock sectors, ranging from state-owned industry and majority state-owned by sector rather than by name in this paper. The final private-public shareholder ownership. The companies are identirst, listed companies in Thailand were not required to archive sample of annual reports was also conditioned by two factors. First, listedcomentally backwards over the eighteen-year timeframe of annual reports and so the availability of reports diminish robust to analyse the post-economic crisis years of the late $1990 \mathrm{~s}$. the study. The final sample was nonetheless sufficiently robust to analyse the post-economilly since 2004 . Secondly, there was a On-line digitalisation has subsequently increased annual report avalabilthist cultural practice in every successive year, tendency in some companies' annual reports not to repeat the details of Buddhist cultural practice in even-disclosure. Years of although subsequent reports confirmed the on-going nature of such practice in intervening years of non-disclosure.

non-disclosure or limited referential disclosure were therefore not included in the final sections of Thai annual reports are

Thai Financial Reporting Standards (TFRS) which are used to construct the financial sections of Thai annual reporic standards. Like identical with International Financial Reporting Standards ( Thai annual reports typically contain mandatory and voluntary the annual reports of listed international companies, Thai annual reports there is in addition a wide range of broader information in the form of financial statistics and financial narrative information. There is in additionawide range of broader 
textual narrative, photographs and locally relevant information on Thailand. This paper demonstrates how such local narrative, social information, and photographs are as important as the financial information in understanding Thai company reports, especially in terms of analysing the normative Buddhist motivations which the reports portray and promote. ${ }^{4}$ Thus analysis shows that in the final sample of 146 companies with 1063 annual reports across the period from 1998 to 2015,100 companies (69\% of 146 sample companies) in one or more years contained narrative and photographs pertaining to Thai Buddhist cultural practice. 65 companies (45\%) utilised Buddhist iconography in their annual reports. 97 companies (66\%) narrated Buddhist gifting practices for the creation of merit. 61 companies (42\%) emphasised the Thai monarchy as a Buddhist cultural pillar of Thai society. These cultural narratives and pictures should not be misinterpreted into some form of religious essentialism or orientalism in Thai accounting practice (vide Said, 1990), although they express the significant presence of normative Buddhist socio-economic practice in the construction and interpretation of company business and annual reports in Thailand in this period. Such normative Buddhist accounting practice exemplifies and expands recent discussion on the need for meaningful engagement with pluralist or multiple perspectives and the locally-contextualised political dimensions of accounting practice which, as this paper demonstrates, lie embedded in so-called universal accounting practice (for example, Gallhofer, Haslam, \& Yonekura, 2015; Brown, Dillard, \& Hopper, 2015; Deegan, 2017; Gallhofer \& Haslam, 2017, pp. 8-9). While the paper does not seek to assess and comment on corporate social and environmental performance or commitment in Thai annual reports (see Kuasirikun \& Sherer, 2004; Kuasirikun, 2011), it emphasises the presence and importance of Buddhist cultural practice in the annual reports and its relevance in understanding the normative motivations that lead Thai companies to contribute in their relational practice to the developmental construction of the Thai economy and society.

\subsection{The gift of mindfulness: Relational business practice in Thai annual reports}

Buddhist cultural and socio-economic practices in Thai annual reports are often expressed in terms of perceptions of the self and the development of mindfulness through practice of the Four Buddhist Truths on the nature, origin, remedy and cessation of suffering (Horner, 1938, I, pp. 15-16). The first Buddhist Truth states that suffering (dukkha) is caused by the unstable nature of the life cycle of birth, ageing, sickness and death. The second Buddhist Truth identifies the origin of suffering in craving (tanha) and over-attachment to self. The third Buddhist Truth emphasises alleviation of suffering by mindful understanding of the craving created by over-attachment to self. The fourth Buddhist Truth describes the Eightfold Path of right practice or Middle Way which prescribes modes of self-regulation to enable mindfulness, control of craving and attachment to self (Bodhi, 2000b, 56: II, 1843-47). In many Thai annual reports, this normative motivation for business practice is expressed in terms of a recursive Buddhist structuration process of development towards mindfulness of the client, customer and corporate self through their relational business practices. In addition to the material profit-based purpose of business transactions, company employees are understood to gift a sense of mindfulness (in Mauss's term, the 'spirit of the gift') through their relational practice with their clients to develop mindfulness in their clients, the company and themselves in return. The gift of mindfulness expresses a normative motivation for everyday business and accounting practices in Thai culture, particularly in terms of expressing probity and corporate social responsibility.

This Buddhist sense of the gift of mindfulness is an inherent characteristic of annual report narratives across a range of sectors in Thailand, although it is epitomised by the annual reports and business literature of the hospitality sector. For example, one of Thailand's most prestigious international hotel chains opened its flagship hotel in Bangkok in February 1970 with a focus on a concept elaborated by King Rama VI (1910-25) in 1918 entitled 'town in heaven'. This concept of a 'town in heaven' is based on the fourth Buddhist heaven (where bodhisattva or incarnations of the Buddha await their last re-birth) in the 14th-century Thai Buddhist text Traiphum Phra Ruang (Three Worlds Cosmology of Phra Ruang) (Reynolds \& Reynolds, 1982). The hotel characterises King Rama VI's 'town in heaven' as an ideal and experimental society that he laid out in Bangkok where people might live in mindfulness, happiness and freedom (McFarland, 1954, p. 332; Company Profile, 2010, p. 1). The hotel seeks to encapsulate this Buddhist inspiration in its business practice. As the hotel expressed in its brand credo, 'we use the gifts of heaven to create heaven on earth' or in its founder's own words, 'in the early 1900s King Rama VI envisioned a wondrous utopia ... It is the inspiration for all we do' (Annual Report, 2010-11, p. 1). In its business outlook, the hotel has sought to draw on King Rama Vl's societal ideal from the Traiphum Phra Ruang to provide a service which gifts mindfulness to its customers, as well as providing them with material comforts (on King Rama VI, see Greene, 1999; Baker \& Phongpaichit, 2005, pp. 105-16).

This sense of a gift of mindfulness in business practice replicates out into different aspects of the hotel, for example the subsidiary spa company which is included in its annual report (2007, p. 9). As the annual report elaborates, the spa is similarly conceptualised as a 'garden in heaven' and re-creates the Nantha garden at heaven's gate in the Traiphum Phra Ruang (Brochure, 2010) as designed by the Thai author Ploy Chariyaves. Textual narrative characterises the mindfulness gifted through this 'garden in heaven' as 'a balance of body, mind and spirit'. Complementary visual representation in Picture 1 provides a Buddhist iconographic portrayal of the five relational divisions (khandha) of the Buddhist 'self': namely body

\footnotetext{
${ }^{4}$ For theorisation of visual narratives, see Macintosh (1990), Tinker and Neimark (1987), Graves, Flesher, and Jordan (1996), Preston, Wright, and Young (1996), Bernardi, Bean, and Weippert (2002); Benschop and Meihuizen (2002), Davison and Warren (2009), Davison (2002, 2004, 2007, 2009), Kuasirikun (2011).
} 


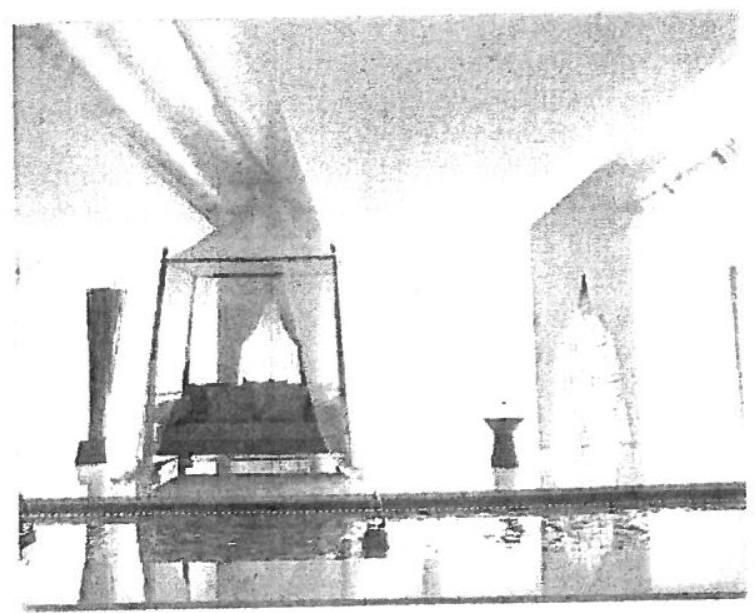

Picture 1. Hospitality Sector (2007, p. 9)

(rupa) and sensation (vedana) (symbolised by the transparent glass stupa as emblems of the physical elements from which the enlightened mind emerges); mind including cognition (sanna) and constructing activities (sankhara) like volition (jetana) (represented by the white-veiled pavilion and royal seat symbolic of the Buddha's kingship); and the spirit of discriminative consciousness (vinnana) (reflected in the brilliant white light which gives the room a quality of creative mindfulness). These divisions (khandha) of body, mind and spirit interrelate trans-actionally through links (nidana) of Conditioned Arising (paticca-samuppada) by which each division relationally influences the development of the others in practice. $^{5}$ In a mode of structuration, past and present practice structures the relational development of the different divisions of the self and they in turn shape successive development of the self towards mindfulness in future practice. Through its practice, the spa company perceives itself as gifting mindfulness by balancing body, mind and spirit in its clients with the aim of enabling a better mindfulness of the impermanence of the self and thereby alleviating the suffering (dukkha) created by their 'journey'. ${ }^{6}$ In Mauss's terms, the spirit of mindfulness in the gift of the hospitality sector's business practice allows relational refocusing of the individual self towards mindfulness (rather than just a material refreshment of the body), and thereby promotes normative development.

While such relational business practice is intended to promote the alleviation of the dukkha of the individual traveller/ customer, the founding vision in the creation of this hotel chain also encompasses a broader social dimension. In its adaptation of King Rama Vl's concept of 'town in heaven' from the Traiphum Phra Ruang, it is the Buddhist Middle Way of social practice that the hotel promotes as a means of its corporate engagement with Thai society for the benefit and merit of company, society and kingdom. The fourth Buddhist Truth, as elaborated in the Eightfold Path of the Middle Way, outlines the generic 'right practice' by which such mindfulness is recursively generated. ${ }^{7}$ The Eightfold Path of the Middle Way is a relational social process in which the components of mind, body and spirit are mutually supportive and trans-actional in the development of suitable discursive and material practices that lead to the alleviation of suffering for individual and social good. The hotel elaborates this concept in terms of its principles of a service which seeks to go beyond the material practices and provisions of a hotel to create a sense of mindfulness and 'an experience that not only uplifts expectations of hospitality, but of our beloved nation.' (Brand credo, 2010-11). In reflection of King Rama VI's promotion of civil society and national identity, at the hotel's business core lies the Buddhist cultural sense of employees providing a service in relational practice with customers and stakeholders which gifts not only a re-structuring of the individual consciousness of those customers/ stakeholders, but also thereby promotes mindfulness in Thai society as well. As Mauss (1925) indicated, the spirit of the gift is seen to generate normative bonds of social cohesion and solidarity for wider society.

\footnotetext{
5 Through the nidana of mind and body which link volition, sensation, cognition and physical form, discriminative consciousness conditions 'constructing activition', condition 6 in self, namely to instil mindfulness that the self is The remedy (proposed by the Third Buddhist Truth) is to remove actice of attachment and prevent the cessation of suffering (dukkha) (Horner, 1938, 1, pp. 13-14; Rhys-Davids \& Woodward, 1917-30, II, pp. 66-68).

7 'Right understanding' enables knowledge of the world as a relational flux of Conditionally Arising phenomena, while 'right thought' recognises the need

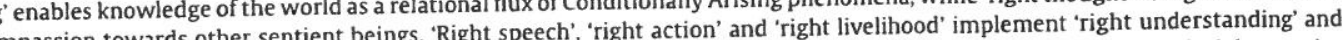
for practice based on compassion towards other sentient beings. 'Right speech', 'right action' and 'right livelihood' imple suffering of others. Such right practice 'right-directed thought' in practice by avoiding deception, improper bodily conduct, and making a living through the self, and 'right mindfulness' and 'right leads to 'right effort', which aims to develop skilful states of mind which limit practices that lead to attachent including the self (see Bodhi. $2000 \mathrm{~b}$ concentration' which represent growing spiritual awareness of the impermanence of Conditionally Arising phenom 56: 11, 1843-47)
} 
Given the normative social bonds promoted by the gift of mindfulness in business practice, Thai annual reports frequently juxtaposed this gift of mindfulness in their company practice with the material vicissitudes of the financial markets and political instability. The Chairman of the Board's narrative in a financial services company report (2006, p. 7) stressed that 2005-06 had been 'a challenging year for the securities business, experiencing various unfavourable factors which affected the overall financial situation' and that 'the major problem was political turmoil that took place around end of year 2005 to the last quarter of year 2006 when a military coup was provoked'. In spite of the impact on the industry overall, the annual report recorded the successful financial measures taken to ensure stability and security in the company's investment portfolio. This emphasis in the narrative of the report on the preservation of moderation and balance in investment practice (in implementation of Middle Way principles) was reinforced by the visual iconography portraying the god Vishnu on his vehicle Garuda as Picture 2 demonstrates. The visual narrative of the god Vishnu, who guards, protects and secures, was used as a background for a group photograph of the board of directors indicating the stability and security of their mindful leadership in a period of political turmoil.

Similarly the image of the bodhi tree in Picture 3 (under which Gautama Buddha experienced the last stage of his meditative search for enlightenment) with the coils of Naga wound upwards around it (representing the Buddha's diminishing involvement with the impermanent world) was also used to expound the board of directors' successful promotion of mindful business practice for its clients in a wider financial world which seemed at that time to be conditioned by unmindful activities, imbalance and impermanence (Annual Report, 2006, p. 14). In Mauss's (1925) terms, the gift of corporate discriminative consciousness facilitates the development of socio-economic mindfulness among customers and wider society and stimulates cohesive social practice in the context of the insecurities of an impermanent world.

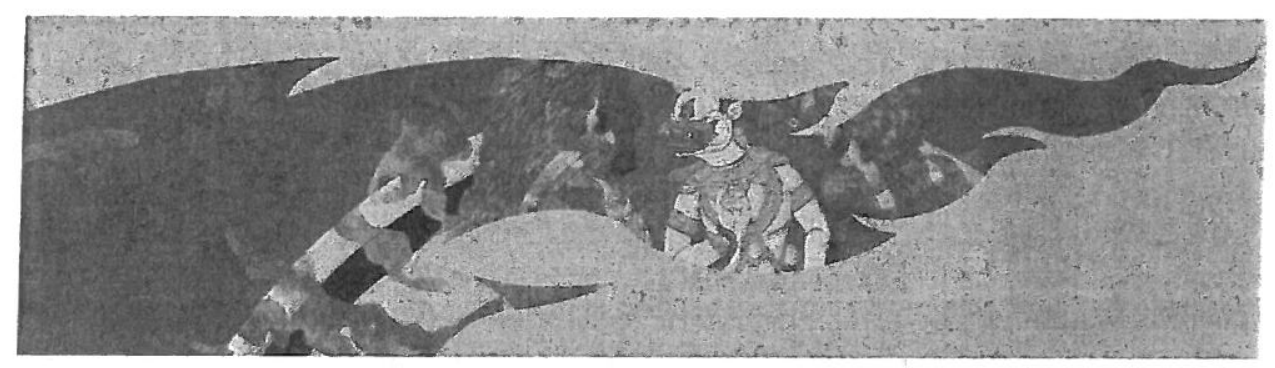

Picture 2. Financial Services Sector (2006, p. 9).

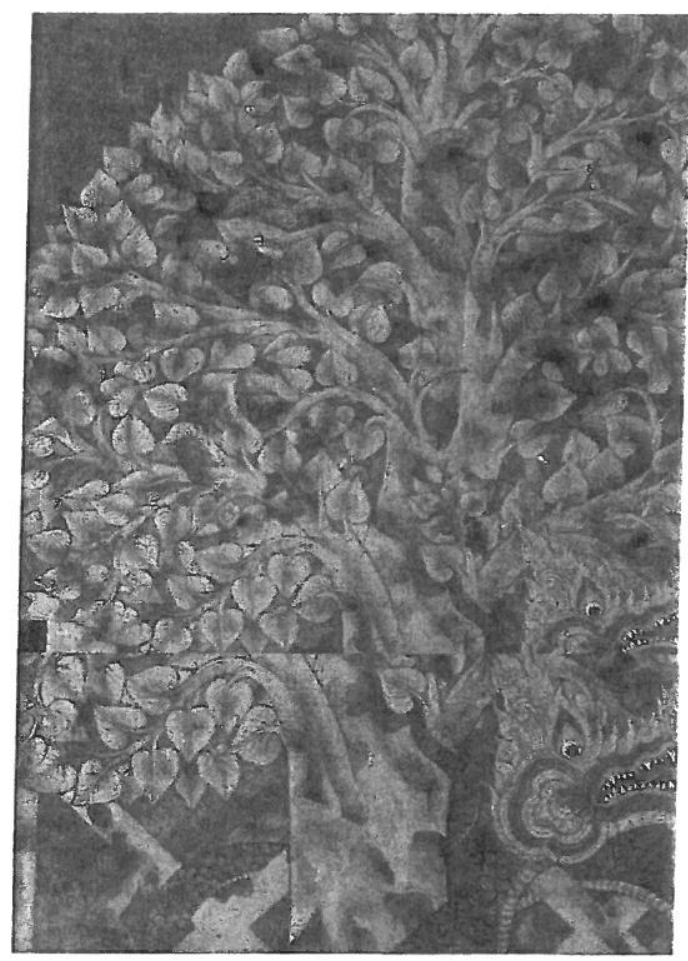

Picture 3. Financial Services Sector (2006, p. 14). 
Furthermore, Thai annual reports frequently use Buddhist cultural practice to explain company performance in response to changes in the external economic environment. For example, a major air-transport company's annual reports from the time of the financial crisis in 1997 recognised business volatility and economic imbalance due to the weak baht and exchange fluctuations, rising fuel costs due to events in the Gulf states, Thailand's move to an open-skies policy for air transport, competition from low cost airlines, and a series of natural disasters such as the Tsunami, SARS and Bird Flu crises from 2004 to 2005 (Annual Reports, 1998-2010). In this context, the company initiated a transformation of its business practice across the period in the privatisation of the company, diversification into lower-cost domestic air transport, its expansion of intercontinental routes, development of connecting flights through membership of the Star Alliance network, and the official opening of Suvarnabhumi International Airport in Bangkok in September 2005 with the aim of becoming 'the aviation hub of the Asia region' (Annual Report, 2004, p. 1). In expression of this new business orientation, there emerged a revitalised sense of corporate identity focused on the gift of high quality service to customers. The company branded itself as 'High Trust, World Class and a Thai Touch' (Annual Report, 2005, p. 6) and 'First Choice Carrier with Touches of Thai' (Annual Report, 2006, p. 2) with the aim of being Asia's preferred airline based on its established strength of customer service and reinforced from 2005 to 2006 by the new service infrastructure of Suvarnabhumi Airport (see also 2008, p. 35; 2009, p. 43, 2010, p. 38; 2011 , p. $125 ; 2013$, inside cover; 2014, p. 10 ).

The company's annual reports in this period explain how this 'service philosophy' was rooted in Thai Buddhist practice, in particular ayatana or practice that creates satisfaction of the six senses (Annual Report, 2005, p. 22). As an annual report (2005, p. 45) indicated, there are six paired internal and external sense bases (eye/sight, ear/hearing, nose/smell, tongue/ taste, body/touch and heart-mind/feeling). One origin of suffering (dukkha) is the craving (tanha) which results for contact in practice between these internal and external sense bases (Bodhi, 2000a; Rhys-Davids \& Stede, 1921-25, p. 105). The aim of company employees in daily practice was 'to deepen relationships between the giver (staff) and receiver (customers)' through 'thoughtful, kind and generous' giving by employees and 'satisfied and content' receiving by customers as a means towards meeting and mindful understanding of such senses (Annual Report, 2005, p. 22). It was thereby intended that 'the highest standard of service, together with Thai-style hospitality and charm, will keep customers satisfied and loyal to (the company), giving it an edge over its competitors and helping it to become Asia's premier carrier and a world leading airline' (Annual Report, 2005, p. 45; see also 2011, p. 43; 2014, p. 10). This service with the aim of both customer material satisfaction and the gifting of mindfulness to meet customer needs was seen to help earn the company merit in return as recognised by the international Skytrax awards for best cabin service in 2005-06 and aircraft cleanliness in 2014 (Sustainable Development Report, 2014, p. 39).

The concept of service/practice which gifts and generates mindfulness in customers was also replicated in the mid and late 2000s in the same company's management practices with employees and flight staff to help them meet organisational transformation necessitated by changing economic times in the air-transport sector (Annual Reports, 2004, p. 45; 2006, p. 5 ; 2007, p. 24; 2010, p. 5). As the 'Message from Management' explained in 2007, 'a new corporate culture, "Thai spirit" is being fostered, focusing on 'Teamwork' - increasing cooperation to create competitive advantage; 'Happiness'-focusing on employees' well-being and happiness at work; 'Awakening' - enlivening with enthusiasm to welcome new experiences and developments; 'Inspiration' - the feeling of being part of an organisation and the desire to succeed; 'Customer Focus' delivering unsurpassed quality service, while also being socially and environmentally responsible' (Annual Report, 2007. p. 5; 2014, p. 94; Sustainable Development Report, 2014, p. 12). During times of economic change, the organisational restructuring of the company was expressed in terms of a sociology of Buddhist relational practice, namely a re-balancing of the collective company-self as a result of a recursive re-structuration of its discriminative consciousness through the relational practice of gifting mindfulness in practice for the merit and benefits which it brought not only to customers but also employees and the company in return.

The same air-transport company's annual report (2004, cover page) also used the painting Thai Form (1999) in Picture 4 by Thai national artist, Preecha Thaothong, to represent the normative balance which the company's gift of mindfulness might bring about in a much wider sense between 'four parties: humans, animals, nature and the environment co-existing in the perfect life-cycles with prosperity'. The (abstract) lotus form in this picture is a common symbol in Thai annual reports for conveying a company's promotion and gifting of mindful practice to wider social and environmental constituencies. Similarly, in the 2000s, a large Thai energy group used visual diagrams of a red lotus with opening petals (for example Picture 5) to emphasise its policy of gifting mindfulness in its relations with the wider community and environment in order 'to maintain the balance between economic return and social and environmental contribution' (Sustainability Report, 2010-11: Annual Report, 2004, p. 4). In the energy company reports, like the air-transport annual reports, the lotus referenced stages of the path of Conditioned Arising in the company cycle of life as the lotus grows out of mud and cloudy water to emerge on the water surface (mindfulness) and finally produce a scented flower (enlightenment). The energy company's lotus diagram suggested in particular a structuration process by which the company enabled the development of discriminative consciousness (harmonization) through free expression of ideas, instillation of a code of business practice, assessment of such practice, and openness to questions, investigation and reporting. This recursive structuring of company discriminative consciousness through service to customers was perceived to enable an increase in mindfulness not only for employees and customers, but also in wider society and the environment of which they formed a part. Likewise, Picture 6 from a Thai oil and petroleum company report (2006, p. 39) shows four children with outstretched arms in abstract representation of an opening lotus surging from the river water and symbolizing a rise of mindfulness in a world where everything is inter-related and exists as part of an endless interlinking flow of kamma. The Thai oil and petroleum company in the background of the 


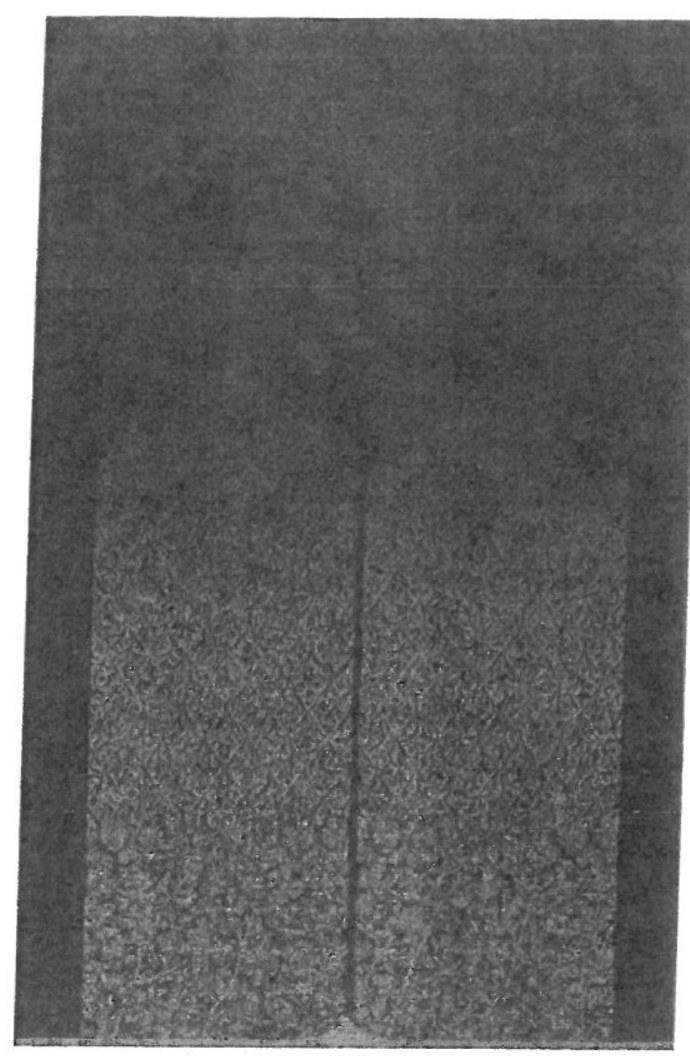

Picture 4. Transport Sector (2004, cover)

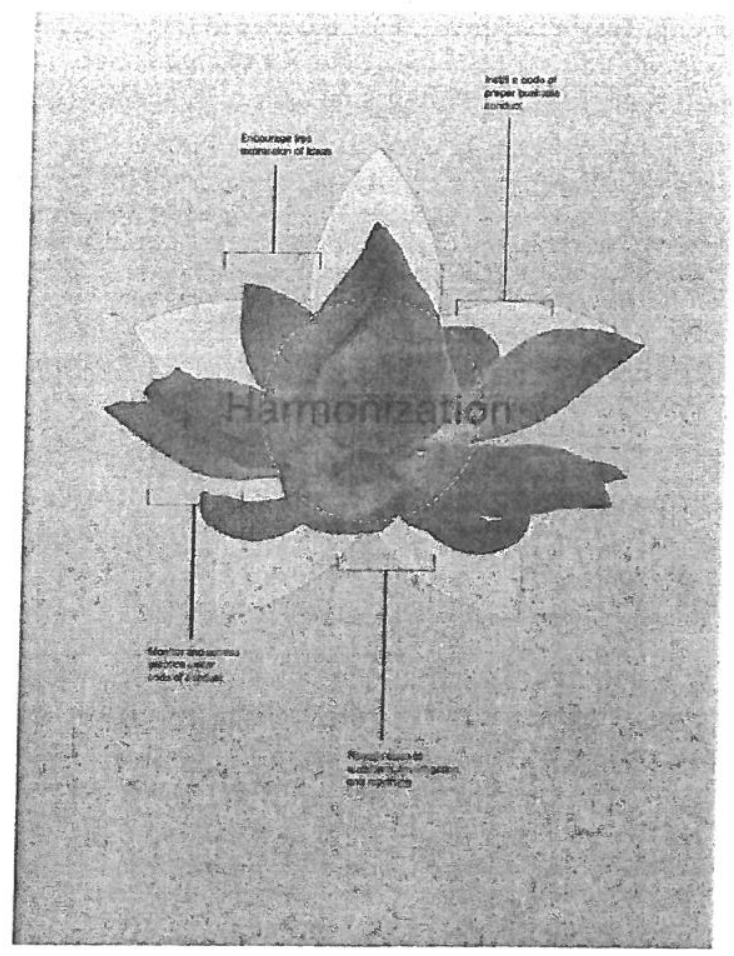

Picture 5. Energy Sector (2004, p. 4). 


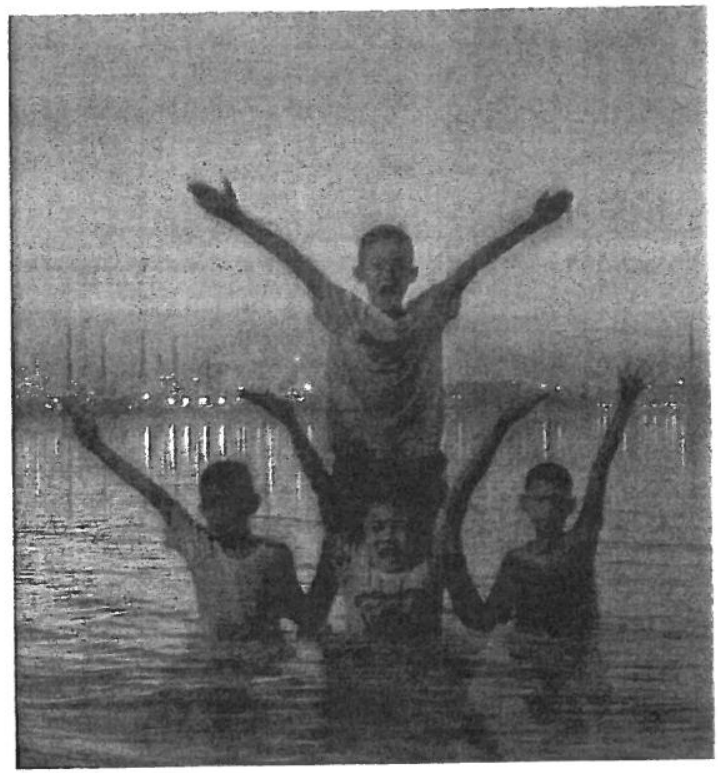

Picture 6. Energy Sector (2006, p. 3).

picture thereby constituted its written social and environmental narrative in terms of a sociology of Buddhist relational practice, namely that the company not merely engages with a network of relations in commercial terms, but also, in Mauss's (1925) terms, gifts in its practice a spirit of normative mindfulness of environmentally-friendly and socially-responsible networks of production for the merit of the company as well as for the benefit and cohesion of future generations of Thai society.

In sum. Thai companies perceive their business practice as a service which gifts a normative spirit (the spirit of the gift in Mauss's terms), as well as selling their material products. As Thomas's (1991) interpretation of Mauss (1925) indicates, gifting is an 'entangled' process which interrelates with commodified forms of market exchange, or in Parry's (1986) terms, persons and things, interest and disinterest are merged. In Thai Buddhist society (which Mauss did not study), the 'spirit of the gift' is mindfulness which facilitates the five relational divisions (khandha) of the customer self to re-balance dynamically through links of Conditioned Arising. This rebalancing also allows the recursive growth of discriminative consciousness which promotes improvement in mindfulness for the merit/benefit of companies in return and for the social cohesion and development of Thai society. Improvement in mindfulness creates such benefit by facilitating a growing realisation that over-attachment to self is the origin of suffering (dukkha) because the self is only an impermanent and transient entity (annica) in a wider flux of relational practices. In a Buddhist theorisation of relational practice in Thai annual reports, the normative agency for transformative change therefore comes not from the individual self or collective structure per se, but from a drive (in the gift of mindfulness) for non-self (anatta) or an understanding that self-agency is only a fragmented and impermanent part of wider flows of agency in patterns of relational practice.

\subsection{Gifting (tamtan) and receiving merit (tambun) in Thai company annual reports}

Another principal means by which mindfulness in employees, customers, companies and society is developed in Thai business practice is in the auspicious activity of material charitable gifting (tamtan), which (like the gift of mindfulness in section 4.1 above) generates metaphysical merit (bun) for the giver in return, in as much as it limits the suffering of the recipient. Unlike Mauss's case studies (1925), the spirit of the gift in charitable gifting is not anthropomorphised in the material gift to require its return, but as commentators on Mauss like Leach (1961) note, a balanced reciprocity is achieved in a different medium, whereby the spirit of the gift is recognised in the return of metaphysical merit to individual and company donors.

Harvey (1990, p. 213) has indicated that the Buddha in the Sigalovada Sutta (Rhys-Davids \& Rhys-Davids, 1977, III, pp. 18093) suggested the importance of ethical relational practice towards six principal groups of people within the social collective, namely parents, wives/husbands, family/friends, employees, monks, and teachers. In broad terms, these categories determine the main patterns of gifting practice which emerge in Thai annual reports. In this survey of the annual reports of 146 Thai companies, 97 (66\%) of the sample disclosed Buddhist practices of charitable gifting to these categories with an emphasis on merit-making. Although some companies quantified their social gifting in financial terms, this information was largely elaborated in terms of textual and photographic descriptions of the relational practice of gifting and merit creation in a wide variety of socio-cultural activities. Many Thai companies and employees were enthusiastic to give material help to family, friends and employees on festivities, sickness or funerals, and misfortune in order to make and share merit (tambun). 
All gave generously to wider community and environmental development projects. Much of the relational practice of gifting also involved the sangha or Buddhist monkhood. Most Thai annual reports recorded substantial gifts to Buddhist temples, monks and their projects. Educational organisations were likewise important recipients of charitable gifts in Thai annual reports. Groups of company employees, their families, networks of associates, educational organisations, sangha and local communities are relationally integrated by this collective merit-making in patterns of practice. Like Mauss's (1925) study, gifting in Thai annual reports is a service performed out of a sense of normative obligation to maintain the collective and wider community. The relational practice of gifting and accumulating merit in return as demonstrated in Thai annual reports generates patterns of material giving and merit receiving that exemplify how routine practice with normative motivation builds incrementally to create patterns of governability that are driven by collective normative judgement and value consensus.

For example, a large telecommunications and media corporation stated its strategic aims as 'creating long-term value through good corporate governance', but also social responsibility through 'a strong commitment towards social contribution' and being a 'good corporate citizen'. Its 2006 annual report demonstrated how this social contribution had been independently recorded by the Thai press, especially in practices which strengthen the creativity of young people and family relationships, such as implemented in the corporation's nation-wide youth Camp Sanook Kid (Annual Report, 2006 cover page and p. 13; see also 2010, p. 10). A multiplicity of youth camp photographs in the corporation annual report (2006 p. 12) corroborated its merit-making activities and social purpose. As the annual report explains, 'the bricks and mortar in the structure of Thai society consist of resourceful youth, good education, and strong family relationships. We believe that young people will play a key role in determining the future of Thai society. If young people are well educated and resourceful, they can realise their full potential. If they are brought up in warm families and a high quality social environment, they will grow up to be the major power steering the country's future social development' (Annual Report, 2006, p. 16). The corporation generated merit by contributing to philanthropic gifting patterns that developed social mindfulness through the promotion of family values with the aim of Thai socio-economic cohesion and development.

This telecommunications corporation complemented this family-focused pattern of gifting practice with more traditional narratives on the practice of kathin or gifting to the sangha (monkhood). Such company merit-making ceremonies of kathin are especially prominent events on royal or national occasions and recorded regularly in numerous other company reports, for example one of Thailand's largest banks (Annual Reports 2005, p. 20; 2006, pp. 24-25; 2007, pp. 22-23; 2013, pp. 80-82). In the case of the telecommunication corporation's annual report (2006), Picture 7 typically represents this pattern of Buddhist relational practice of gifting and receiving merit in return through the trans-actional relationship of company employees with the sangha. In this relationship, company employees donate many auspicious items of Buddhist offering. The Buddhist narrative behind this (and many similar) photographs relates to the young woman Suchada, who gave the Buddha a bowl of rice and curds to give him the strength to take his final steps towards enlightenment. It stresses the important practice of the Middle Way between austerity and attachment in daily existence as a mindful balance for individual, company, society and state (symbolised by the Thai flag in the background). Through their relational practices of giving and receiving merit between company and the sangha, the narrative of this telecommunication corporation's annual reports, like many company reports, promotes the Buddhist practice of the Eightfold Path of the Middle Way as a means of structuring patterns of practice for a better Thai society.

In addition to merit-making donations to family-focused projects and the sangha in the form of kathin, many Thai companies also promote gifting for the direct inculcation of Buddhist religious values as a means of structuring a better Thai society. Numerous Thai companies from a range of sectors donate sums annually to purchase land for Buddhist institutions, to build wat or temples, to install Buddha images, to construct Buddhist assembly halls, to maintain Buddhist archives, and to fund training programmes for novice monks (see, annual reports in the insurance/financial services sector (2006, p. 50); steel

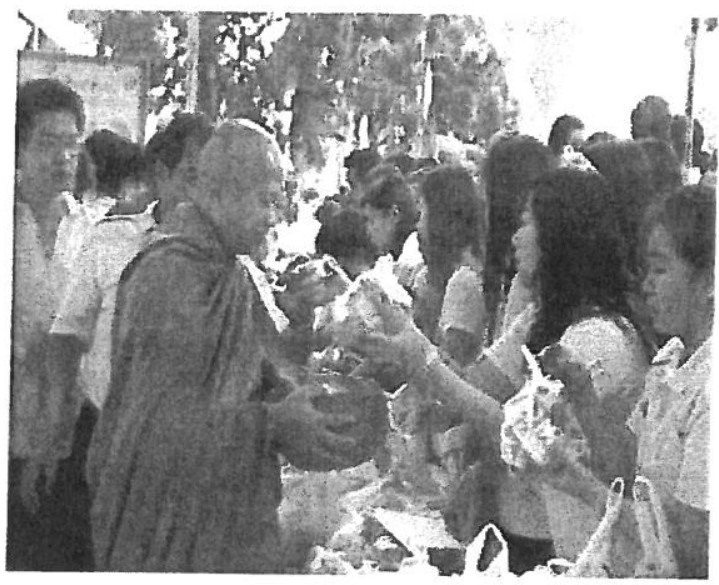

Picture 7. Telecommunications Sector (2006, p. 12). 
production (2006, p. 24); chemical industry (2006, p. 37); textile sector (2006, p. 44); financial services (2006, p. 66; 2007 , p. 79; 2008, p. 86); telecommunications (2007, p. 10); and fabric and clothing production (2007, p. 94; 2008, p. 12). Many company annual reports, such as in the telecommunications sector (2006, p. 17), hospitality sector (2006, p. 19) and fabric and clothing production $(2007$, p. $94 ; 2008$, p. 12) also record widespread support for local Buddhist festivals, such as gifting large Buddhist Lent candles to Wat Nakorn-in, Nonthaburi, organising annual candle-floating processions at Wat Baan Don, Thalang district, Phuket, or candle-moulding ceremonies in Wat Chong Nonthri, Bangkok, respectively. The candle is a symbol of mindful development and progressive enlightenment, and participation in such festivals is not simply promotional, but an example of the Buddhist relational practices in terms of which many companies conceptualise their business practice. As one textile company (2007, p. 27) affirmed, 'we realise the importance of religion in building a better society where people are guided by fine religious principles, enabling people to co-exist in peace, harmony and happiness. We therefore continue to support religion as a fundamental pillar of Thai society'.

A number of companies also annually describe their Buddhist gifting practices for the moral education of their employees. A large publishing company's annual reports (2006, p. 58; 2007, p. 93; 2008, p. 87) describe year-on-year its Dharma Project to 'promote and propagate Buddhism'. The company states that 'beyond our core mission in creating quality print matters, the company also supports activities benefiting employees' quality of lives and enhancing employees' health by strengthening their bodies and souls to promote employees' unity' (2007, p. 92; see also 2014, p. 79). The company perceives the gift of Buddhist mindfulness to their employees as a holistic means of ensuring employee welfare (body, mind and spirit) and creating harmonious relations within their organisation by collective merit-making, as well as being of benefit to the cohesion and development of wider Thai society. Their reports contain a range of photographs of employees participating in such training with Buddhist monks or related merit-making events. Such relational Buddhist practice is common across sectors. A financial services company (Annual Reports, 2006, p. 16; 2007, pp. 14-16; 2008, p. 14) provides similar photographs with narrative about its gift of Buddhist meditative and ethical training for its empioyees, their famiiies and wider public at Bor-ngem Bor-thong monastry. A marine transport construction company (Annual Reports, 2012, p. 3; 2013, p. 131; 2014, p. 139) arranged monthly talks on Buddhist teachings over many years 'to provide a moral compass to employees.' Another clothing company (Annual Reports, 2008, p. 130; 2014, pp. 92-94) stressed as a part of company practice 'the importance of developing inner serenity, the conscience, and the concentration leading to a happy life, together with the crucial role of promoting positive thinking, forgiveness and the pursuit of good, allowing employees to become accountable members of both their families and society.' The gift of Buddhist moral education to employees is prominent in many company annual reports across a range of sectors with the aim of generating company and societal unity.

As well as religious and moral instruction of their employees, many companies sought to gift educational development to wider Thai society. These educational development projects were often focused on communities which were local to the sites of the companies, especially in less developed regions. For example, a petro-chemical company (Annual Reports, 2008, p. 82; 2010, p. 87) promoted a 'Buddhist Succession Project' to promote Buddhist morals and ethics in 2008 and a 'Buddhistheart for New Generation Project' and a 'Youth Training at Wat Ta Khun Moral Center Project' in 2010 to engage young people in surrounding communities in Buddhist-oriented educational activities as a basis for adult life. This was complemented by a range of historical education projects and scholarships for disadvantaged children. A leading Thai bank's annual reports (2007, p. 36; 2008, p. 37) focused on its long-term 'Beautiful Kids with Dharma' Project with its aim of educating Thai teenagers to become balanced adults through Buddhist values of self-esteem, respect for parents and following dhamma. Taught to large numbers of teenagers by a team of monks led by Phra Maha Sompong Talaputto from Soi Thong temple, the bank sponsored 'up-beat Buddhist training' across the country wherever the bank had branches. Similarly, through the sangha in association with local people, an important mining company (Annual Report, 2007, p. 23; 2008, p. 23) initiated both community education and health/social welfare funds in rural districts near its activities. In terms of practice of the Eightfold Path of the Middle Way, the annual reports of Thai companies establish patterns of company educational gifting and receiving merit in return as a means of reducing suffering by developing right livelihood, right speech and right action through respect for others, and right-directed thought in the form of compassion for the less fortunate in the development of wider Thai society.

As Mauss (1925) argued in a different context, the relational practice of gifting and receiving merit in return is therefore a means of building relational practice which promotes societal cohesion. Like the gift of mindfulness which invests sold goods in Section 4.1, patterns of charitable gifting by companies in terms of family, sangha, employees and education enable not only material benefit, but also mindful normative challenge to socio-economic suffering (dukkha) and its potential for fracturing Thai society. Charitable gifting certainly has its limits in remedying suffering. As Bowrie's (1998) study of poor Thai farmers' views of gifting demonstrates, material charitable gifting is seen by its critics as a palliative to solving structural working-class poverty. Nonetheless patterns of gifting practice are consciously driven by the normative values of what Mauss called the 'spirit of the gift', or the 'gift of mindfulness' in the Thai context, namely a drive to relieve suffering (dukkha) and create socio-economic improvement in Thai society by mindful understanding of the self as a fragmentary and impermanent part in wider patterns of relational practice.

\subsection{Annual reports, Buddhist relational practice and the Thai state}

Company patterns of gifting practice, such as those arising from the gifting of mindfulness through service or sold goods (Section 4.1) and charitable gifting with the aim of mindfulness and merit creation (Section 4.2), are important factors in the 
construction of Thai society and state in both material and discursive terms. In material terms, the micro-relational practices of employee and company gifting translate into patterns of relational practice associated with royal organisations, which focal point of Thai society. In discursive terms loyees from different social groups with the Thai monarchy as an integrative patterns of gifting/merit . In this discursive past lives and exemplary virtue or barami inch is viewed as a bodhisattva or Buddha-like leader with outstanding merit from in the present. As Ohnuma return for the donor, but the others and the accumulation material benefit of generated out of multiple of merit in wider society. In the business context, this discourse of Buddhist sovereignty is organisational patterns with the purpose in Thai annual reports detailing material gifting practice to royal projects/ in socio-economic deveerthe purpose of supporting the charitable activities and Buddhist insights of the King of Thailand discursive statements about gifting national integration. To elaborate and expand Mauss (1925), gifting practice itself and collective activity that recursively condition (such as in annual reports) generate normative relations which form patterns of in the social collective.

Thai company annual reports therefore frequently emphasised the focal role of the late King Bhumipol Adulyadej (19462016) at the centre of patterns of charitable gifting practice. Picture 8 from a leading marine construction company (Annual company (Annual Report 2007 , indicates the King as the Great (Naval) Engineer, while another telecommunications projects for the economic prosperity and sover) indicates through Picture 9, how the company contributed to the King's prominent throughout most The people. Such royal-focused patterns of philanthropy are with especially substantial amounts being gifted for merit creation on

The different patterns of company project-patterns for societal improvement practice detailed in Section 4.2 have built up over time in support of two broad economic welfare. In bank (Annual Report, 2005, p. 20) sponsored patterns of practice, for example, the charitable gifting of one prominent Thai bank (Annual Report, 2005, p. 20) sponsored the third stage of the 'Sustainable Forestation Project' (Annual Reports, 2003-

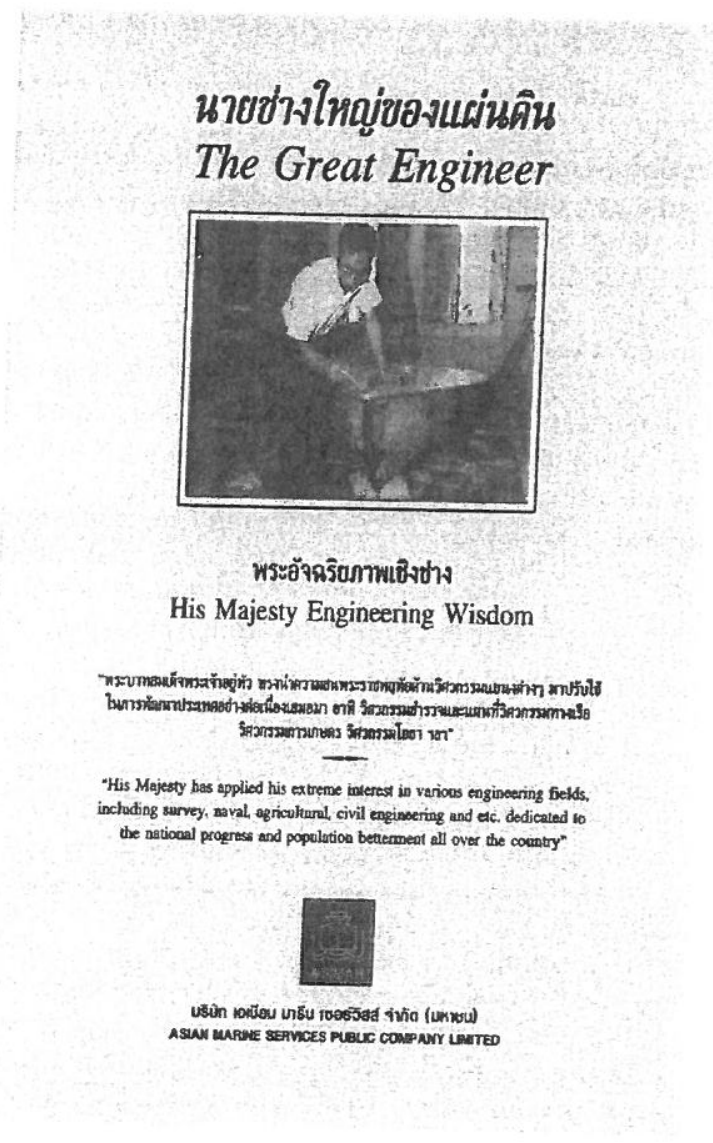

Picture 8. Marine Services Sector (2006, p. 1). 

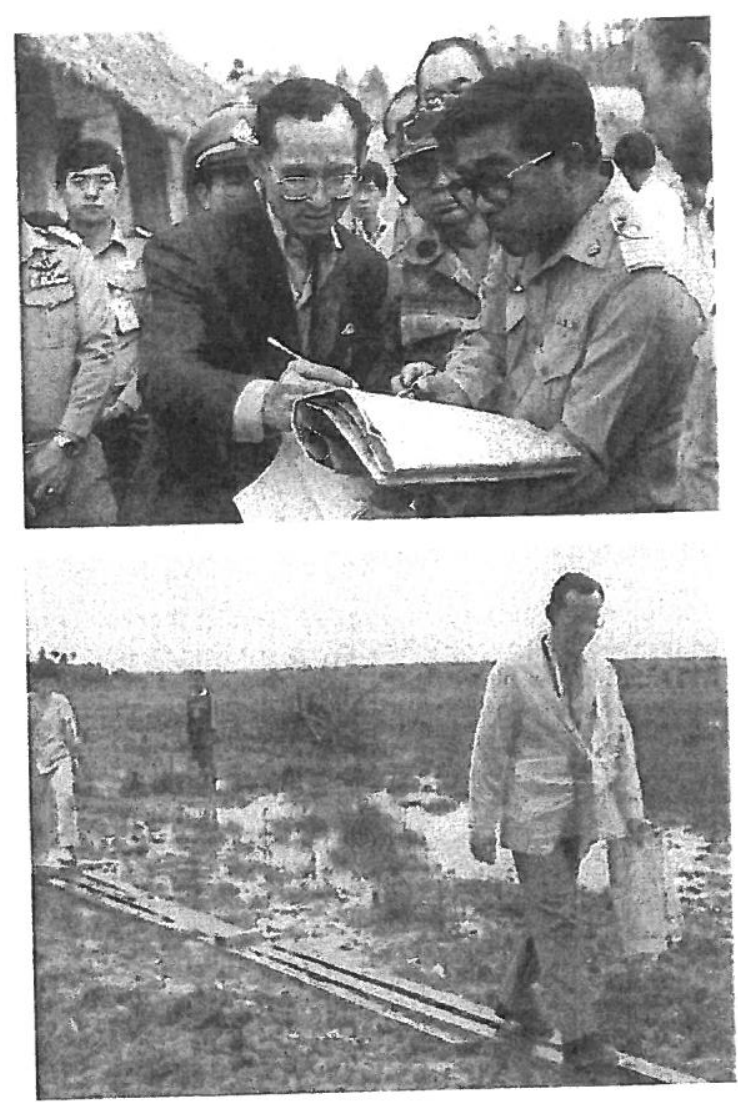

Picture 9. Telecommunications (2007, Inside front cover).

2007), originally established to celebrate the 50th anniversary of the King of Thailand's accession to the throne, while an (Annual Report, 2007, p. 10) initiated the 'Tree of Lineage Project' to plant 3 million combat deforestation. The above-mentioned marine construction company also contributed to royal reforestation aims in Laemfapha Municipality in 2012 (Annual Report, 2012, p. 3). A leading mining company (Annual Report, 2007, p. 18) joined with Mahidol University in 2007 to implement the 'Power Green Camp 2' for students to put into practice the initiatives on sustainable environment that are promoted in the speeches of King Bhumiphol Adulyadej. Likewise, a Thai construction company (Annual Report, 2007, p. 30) in cooperation with the Chai Pattana Foundation launched the 'INSEE Choject' to build dams in northern Thailand for better water management for agriculture. In these ways, company patterns of environmental practice contribute to royal project patterns over successive years in support of long-term aims of mobilising public opinion against environmental degradation in Thailand.

In terms of socio-economic project-patterns of practice, a leading Thai bank supported the Queen of Thailand's longerterm aims of investment, education and integration of less developed and unsettled provinces like Pattani, Yala and Narathiwat in southern Thailand. In the wake of the Tsunami in 2004, the same bank (Annual Report, 2005, p. 37), like many Thai companies, also collected funds for the Royal Rachaprachanukroh Foundation and Thai Red Cross Society to help victims nity regeneration in south Thailand. Similarly, a Thai media company (2006) emphasised its corporate social practice through Sarnrak Family Support Projects which promote closer family relations in support of 'social strength and stability' (Annual Report, 2006, p. 7) 'based on the belief that a strong family will lead to a strong society, and a strong family will lead to a strong nation' (Annual Report, 2006, p. 48). The pattern of its company practice is described in detail in its ranging from newsletters, seminars, television programmes, Children Development Centres under the auspices of Princess Maha Chakri Sirindhorn and a Fund for the Elderly under the Royal Rachaprachanukroh Foundation (Annual Report, 2006, pp. 49-50). Picture 10 of its gifting to the Royal Rachaprachanukroh Foundation linked the company's family-focused patterns of corporate social responsibility with the Buddha at enlightenment, opening red lotuses representing compassion, and the royal emblem on the yellow banner beside a portrait of King Bhumipol Adulyadej, whose reign is perceived to incarnate the Buddhist Middle Way. The picture re-enforced the textual narrative of this company's compassionate and mindful practice which relieves the elderly's suffering (dukkha) and builds integrative family relationships in association with royal project-patterns within the kingdom of a Buddhist king. In this sense, employee

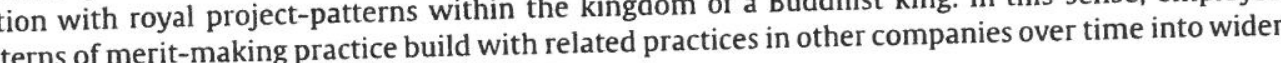




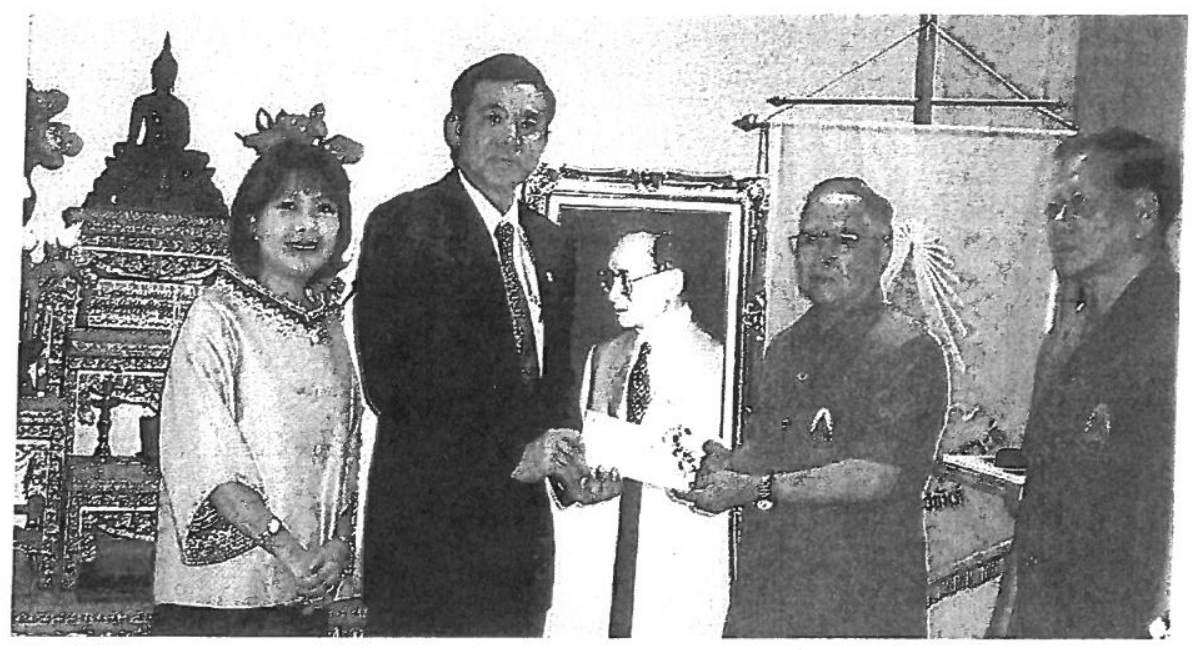

Picture 10. Media Sector (2006, p. 51).

socio-economic project-patterns with the monarchy at their organisational axis, all motivated by the normative purpose of societal integration and improvement.

Another factor for Thai national development is the political stability that is promoted by these relational patterns of gifting practice with the monarchy at its core, especially at times since the early 1990 s when there has been turbulence in Thai politics, economy and society. Baker and Phongpaichit (2005, pp. 235-38) have indicated that, since the military governance of Prem Tinsulanonda in the 1980s, the role of the Thai monarchy has become increasingly 'transcendent' with 'the monarch as a modern thammaracha (Buddhist ruler) and a moral counterweight' to the military and business. As economic liberalisation has occurred and business sectors have asserted their influence in Thai politics since the 1990s, increased political competition has developed with agricultural, government-bureaucracy and military interests. In this context, the axial role of the monarchy in promoting political stability has becoming increasingly important for companies in their Thai annual reports (and for other sectors as well) as the business sector seeks to negotiate stable economic conditions and political relationships with other sectors with a view to national development. Thus, an important Thai textile manufacturer (Annual Report, 2007, p. 27) emphasised its support for the monarchy in association with Buddhism and nation as fundamental pillars of Thai society, which together maintain business practice and ensure stability. In one of Thailand's main insurance company's annual reports (2006, p. 27), which was filled with pictures like Picture 11 of celebrations of the 60th anniversary of the King of Thailand's accession to the throne, the company affirmed the important relational role that the monarchy is perceived to exert in creating equilibrium in Thai society. These discursive statements are confirmed by the myriad patterns of corporate social practice in which the company is involved, ranging from contributions to royal charities like the Ananda Mahidol or Chai Pattana Foundations, educational scholarships, a Fond-of-Reading Project

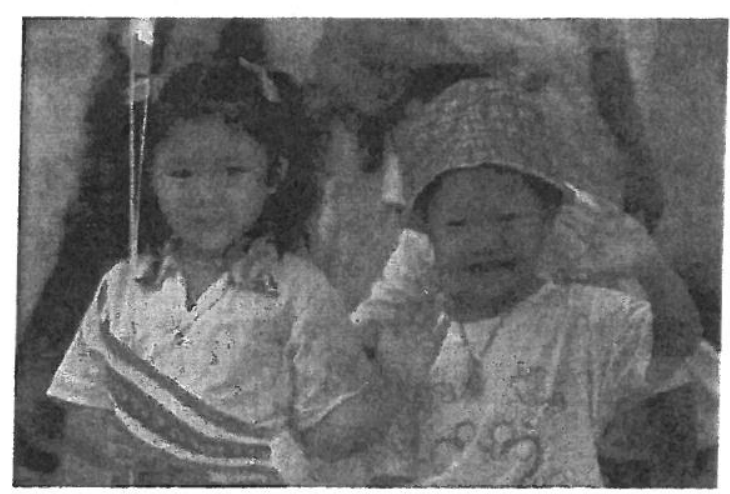

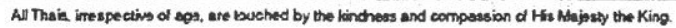

Picture 11. Financial Services Sector (2006, p. 27). 
for Thai schools, donations to the Princess Sirindhorn Foundation for mobile medical units, and an impressive Thai heritage project including a museum of early Thai artefacts (Annual Report, 2006, pp. 48-50; Visit to the museum, December 2010). Similarly, on the 60th anniversary of the King of Thailand's accession to the throne, a large gas and petroleum company annual report (2008) emphasised the role of the Thai monarchy as the relational axis for the societal stability and national interests of all generations and communities of Thai people. This report entitled 'Our 30 Years of Determination' stressed 'three decades of (its) resolute commitment to forging ahead for stability while striving for excellence' in its search for national energy security for Thailand, most notably in the development of natural gas and alternative fuels, like ethanol, biodiesel and gasohol, in association with Royal Chitralada Projects (Annual Report, 2008, pp. 3, 9). Picture 12 from the same gas and petroleum company's annual report (2008, p. 144) complemented this narrative with the visual image of the Thai Buddhist monarch King Bhumipol Adulyadev overseeing with mindful compassion the different communities, sectors and generations of a stable and unified nation. In such annual reports, the monarchy provides the relational axis for projectpatterns as a means of promoting Thai political stability in a society undergoing rapid re-balancing of its economic sectors and concomitant social change.

Complementary to the role of Buddhist kingship as the relational axis for company gifting and merit-making, many companies in various sectors have also been inspired in their contributions to social and environmental project-patterns by the emphasis on the Buddhist Middle Way discourse of King Bhumipol Adulyadev in terms of socio-economic 'sufficiency' principles. These principles seek to instil in Thai people the concept of living a conscious and knowing life towards themselves and things around them on the basis of sufficiency and logical decisions' (Annual Reports: Financial Services, 2008, p. 14; Publishing, 2006, p. 70: for discussion of sufficiency principles see Bergsteiner \& Dharmpiya, 2016). A leading clothing company (Annual Report, 2007, p.121), for example, launched a wide range of practices for its employees in support of Buddhist 'sufficiency' principles in celebration of King Bhumipol Adulyadev's 80th birthday. These included personal development of the self through projects such as 'planting trees of good deeds', 'prayer, meditation and concentration for the King', 'giving food, planting virtues for the King', a 'Love the King, Care for Health' programme, and a 'Good Deeds, Sufficiency Life' campaign to instruct people in managing household budgets and saving for the future. Other companies in food production and the construction industry have also adopted sufficiency principles as the basis for corporate management strategy (see Kantabutra \& Winit, 2016; Rungruang \& Ractham, 2016). Furthermore, the King of Thailand's statement of sufficiency principles has found wider social expression in a range of corporate social practice in establishing schools in poorer rural areas (Annual Reports: Chemical Industries, 2006, p. 37; Telecommunciations, 2006, p. 14), hospital provision for poorer communities and regions like the Wat Chan hospital in Chiang Mai (Annual Reports: Distribution Services, 2007, p. 154; Textiles, 2006, p. 113; 2008, p. 123), blood donation to the Thai Red Cross (Annual Reports: Financial Services, 2007, p. 22; Textiles, 2008, p. 123), and contributions to the Thailand Association for the Blind under the patronage of the Queen of Thailand (Annual Report: Telecommunications, 2007, p. 10), as well as funds donated in pursuit of traditional Buddhist practice of saving cattle from slaughter for re-allocation to poor farmers (Annual Reports: Textiles, 2006, p. 113; 2007, p. 123; Equipment Manufacturing, 2008, p. 57). Material relational practices of gifting in return for merit have therefore been articulated discursively in terms of Buddhist principles of 'sufficiency' as a means of relieving suffering (dukkha). Thai annual

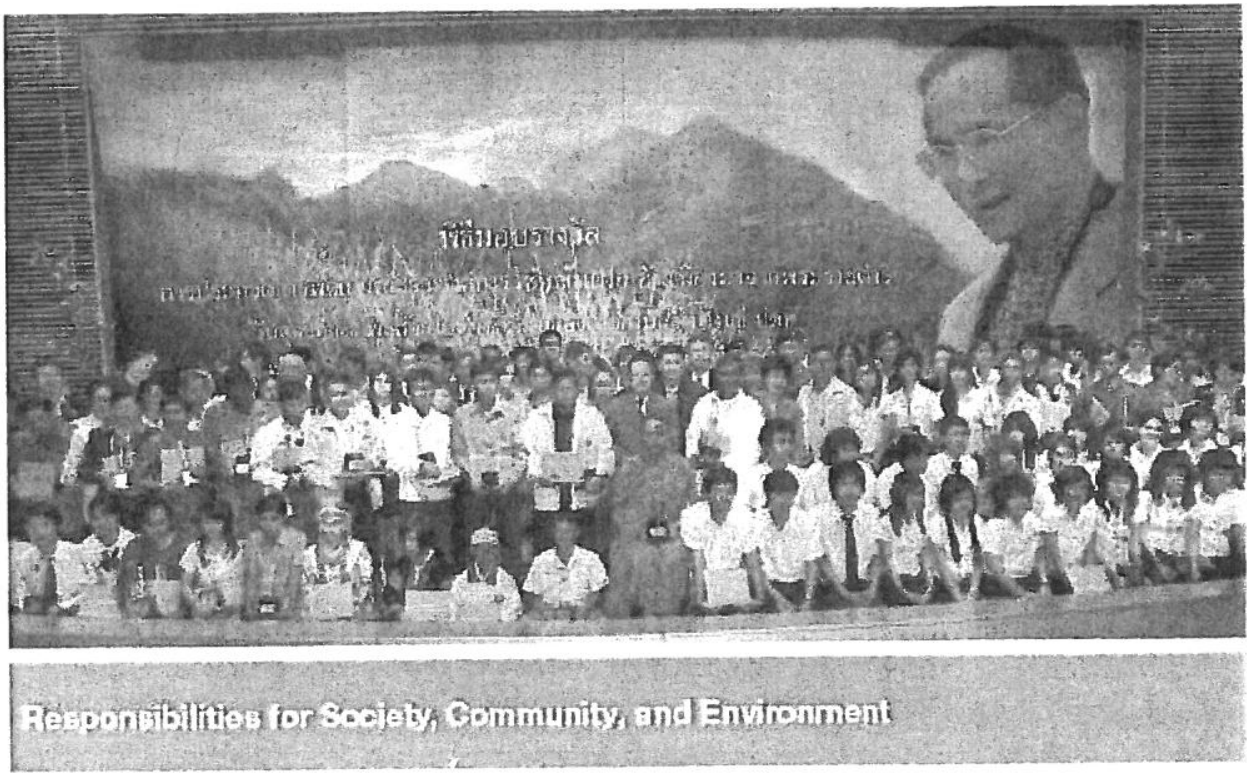

Picture 12. Gas \& Petroleum Sector (2008, p. 144) 
reports record and promote this translation of employees' normative practices into corporate and royal project-patterns in fulfilment of the Buddhist Middle Way discourse of sufficiency for the socio-economic integration and stability of Thai society.

The monarchy's axial role in creating integration and stability is also further elaborated in terms of the connection of patterns of gifting practice with a wider Buddhist moral order. As the background of Picture 12 demonstrates, the Thai monarchy is considered to link the kingdom vertically with higher Buddhist moral realms on the slopes of Mount Meru which the early Thai text Traiphum Phra Ruang (Three Worlds Cosmology of King Ruang) (Reynolds \& Reynolds, 1982) lays out as the order of the Buddhist cosmos. ${ }^{8}$ In its modern metaphorical interpretation, as Jackson (1993), Reynolds (1976) and Reynolds (1978a, 1978b) indicate, this cosmology continues to invest contemporary Thai practice as a normative order for integrated and stable Thai governance in the late 20th and early 21 st centuries. The role of the Buddhist monarch continues to be governance of his kingdom to ensure material sufficiency, wisdom and justice for his people based on his merit, barami or exemplary virtue, and enlightenment as a bodhisattva. By juxtaposing a cosmologically-oriented background to the King of Thailand with the unity in diversity of the Thai nation in the foreground, Picture 12 illustrates in this gas and petroleum company's annual report that the Thai monarch is perceived not only to be a socio-economic axis that materially and discursively relates the patterns of gifting practice of the different sectors and communities of the Thai kingdom. The monarchy's axial role is also perceived in broader terms to connect normative patterns of practice, charitable projectpatterns and the kingdom with the wider moral order, stability and unity of the Buddhist cosmos.

As many later commentators on Mauss (1925), like Sahlins (1963), Gregory (1982), Weiner (1992) and Schrauwers (2004), have however emphasised, prestation and its returns not only establish the socio-economic integration and stability of the collective, but also infuse the social collective with status, hierarchy and power relations. In the Thai context, the overall accumulation of merit through gifting to royal charitable project-patterns by one sector of the economy aggregates degrees of merit that confer status and authority in generic terms on that economic sector in relation to other sectors. Charitable gifting and receiving merit in return have become one of the ways in which the Thai business sector has exhibited its rising influence in Thai society and politics from the 1990 s as the development of economic liberalisation and concomitant political competition with other established sectors have emerged. In this way, while employee and company gifting in individual and company terms is normatively motivated and generously donated for development purposes, Thai annual reports also come to encapsulate a power-based construction of the Thai state within which competing sectors (business, agriculture, government-bureaucracy and military) realise their relational association with the Thai monarchy to the benefit of their sector based on the perceived advantages that their sector's activities will bring to the development of the Thai economy. In this general sense, Thai annual reports epitomise not only a normative developmental drive but also a political debate that lies at the heart of 21 st-century Thai society about the future nature of the relational balance of power between socioeconomic sectors in Thailand under a constitutional monarchy.

Ultimately, the annual report of a large plastics and chemicals company in 1998 epitomises this relational construction of the role of the Thai monarchy as the axis of a nexus of patterns of gifting/merit-making practice for the integration, stability and sustainable development of the Thai kingdom within a wider Buddhist moral cosmos. When Thailand faced financial difficulties in the late 1990s, this company annual report (1998) included the popular Buddhist narrative of the Mahajanaka Jakata from an edition by King Bhumibol Adulyadej (1996) with a theme entitled 'building a solid foundation for sustainable growth' (Annual Report, 1998, front page). Using the example of a storm and shipwreck of Prince Mahajanaka-kumara on his way to Survarnabhumi (Thailand), the Mahajanaka Jakata describes the resolve of the prince as he swam for seven days to the shore after all others drowned. Throughout the annual report, narrative excerpts from the Mahajanaka Jakata and paintings of the Mahajanaka Jakata by Thai national artists were inserted to emphasis the prince's perseverance in riding through the storm cycle of life, such as exemplified in Picture 13 by the Thai national artist Pichai Nirand. The determination of Prince Mahajanaka-kumara was used as a metaphor for the company's tenacity in implementing the Buddhist insights of Prince Mahajanaka-kumara and King Bhumibol Adulyadej as a means of resolving financial crisis and national suffering in 1997-98. Moreover, the company's annual report (1998) promoted a further corporate social message derived from the Mahajanaka Jakata, namely the need in future to avert such crises. Once returned to his throne, Prince Mahajanaka-kumara visited and picked the fruit of a mango tree in the royal park, but his people in conflict with each other tore up the tree in their greedy pursuit of mangoes. The annual report pointed to a need for Buddhist Middle Way practice to remedy people's lack of understanding of what is beneficial for society and to realise Buddhist mindfulness/self-lessness, moral balance and 'sufficiency' rather than excess in practice (Annual Report, 1998, pp. 58-59; King Bhumibol Adulyadej, 1996, preface, pp. 68, $70,95,115,125)$. In their annual reports of the late 1990 s and 2000 s, the company recorded putting into practice such mindfulness and sufficiency principles in terms of gifting school construction projects in Rayong province, community development in Map Ta Phut and Ban Chang, and a Cultivation of Coral Collaboration for His Majesty the King (Annual Reports 1998; 2008, p. 210; 2010). In reflection of Mauss's (1925) analysis, the company's gifting practice contributed materially to patterns of charitable donation and royal developmental project-patterns of the Thai kingdom with the monarchy at its axis, while the company's statements about its activities in terms of the Buddhist Middle Way practice of

\footnotetext{
${ }^{8}$ The Traiphum Phra Ruang describes the Buddhist self and mindfulness in terms of thirty-one hierarchical realms of merit (bun) on Mount Meru. At its summit is located the city of the thirty-two gods, Sudarsana, with further non-corporeal realms of mindfulness above, while on its slopes are lower realms and among the four cardinally-arranged continents that surround it lies the southern continent of human-kind, Jambudvipa (Heine-Geldern, 1942)
} 


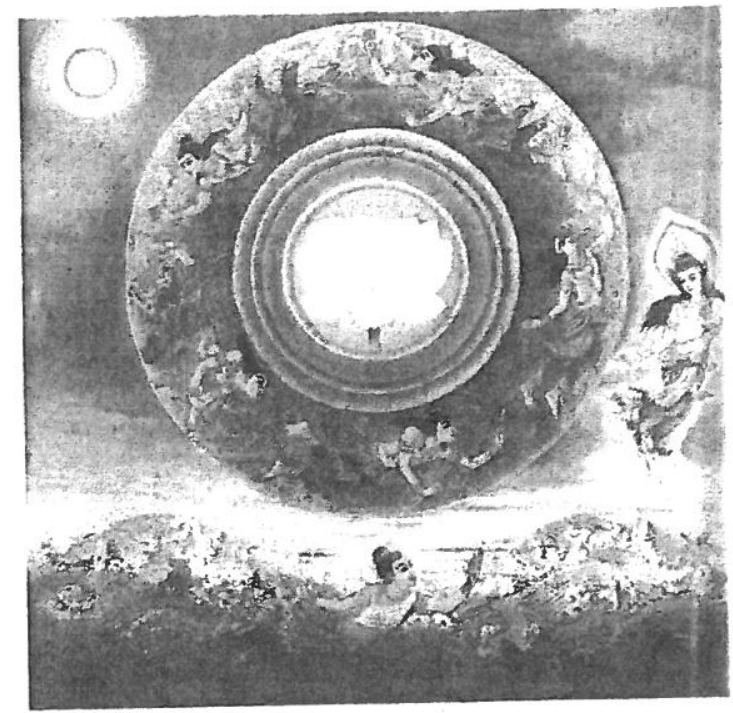

Picture 13. Plastics \& Chemicals Sector (1998, p.60).

'sufficiency' contributed to a consensual discursive construction of a constitutional monarch as bodhisattva of a stable and cohesive Thai kingdom within a wider Buddhist cosmic order.

In sum, to elaborate on Mauss's (1925) theorisation, gifting practice and merit earned (such as evidenced in Thai annual reports) create relations whose shared normative values serve to consolidate corporate patterns of practice into wider project-patterns which promote the social integration, economic stability and normative equilibrium of the Thai polity. This nexus of gifting patterns and statements about such gifting patterns in Thai annual reports also contribute to the construction of the sovereignty of the Thai constitutional monarchy as a moral axis for the cohesion and stability of Thai society and state. This royal sovereignty emerges in particular from popular normative understanding of Buddhist Traiphum order and Buddhist Middle Way practice based on 'sufficiency', which has come to be popularly epitomised by the Mahajanaka Jakata in early 21st-century Thai society. Like the commentary on Mauss by Sahlins (1963), Gregory (1982), Weiner (1992) and Schrauwers (2004), prestation also establishes status hierarchy and power relations within the social collective, whereby gifting bestows degrees of merit in return that give changing status and authority to different sectors within Thai society as they interrelate and seek to determine the future development of the Thai state. This Thai Buddhist Middle Way order is not materially and discursively constructed by (what Emirbayer (1997) terms) the 'self-action' of individuals, collective actors, structures or state, but is explained in terms of a Buddhist theory of relational practice by evolving trans-actional patterns of practice which are driven not only pancratically or instrumentally in practice, but also by the normative Buddhist values which invest these multiple practices.

\section{Conclusion: Towards a Buddhist relational theory of Thai accounting practice}

As Section 4.1 has argued, Thai annual reports express a Buddhist relational practice in which employees, employers, clients, companies and stakeholders are characterized in terms of a Buddhist form of structuration: namely involvement in commercial practice that gifts mindfulness (Mauss's (1925) spirit of the gift) to allow the recursive growth of discriminative consciousness through a process of Conditioned Arising, thereby enhancing a flow of normative understanding in future practice. This gift of mindfulness in practice in Thai company reports projects the normative motivations of business practice and provides a vision of the desirable social ideals which invest that practice. Secondly, as Section 4.2 demonstrates in terms of Mauss (1925), charitable gifting and receiving merit in return are perceived by companies as normative relational practices for generating a Buddhist Middle Way in collective patterns of normative practice which contribute to the integration, stability and development of the societal whole. Thirdly, in Section 4.3, by fostering normative gifting practice based on a Buddhist Middle Way among employees, families, clients, stakeholders and wider groups, companies contribute to the consensual construction of relationally-integrated patterns of practice for Thai society with the Thai monarchy as a recognised socio-moral axis. These material and discursive patterns of practice are self-constructed by their relational generation out of the normative micro-practices of employees and their families. Patterns of corporate practice translate into charitable project-patterns which include royal organisations, sangha and development agencies, and facilitate the construction of a normative consensual order and consciousness for societal integration, stability and improvement focused around a sovereign constitutional monarchy. 
The insights of Mauss (1925) help in part to elaborate this Buddhist relational theory of practice. First, Mauss emphasises socio-economic activity which is not determined by (what Emirbayer (1997) terms) the 'self-action' or 'inter-action' of singular individuals or collective structures, but by the dynamic relational 'trans-actions' in practice of a multiplicity of agents, institutions and collectives. Secondly, Mauss (1925) argues that relational practice is not between individual selves per se, but members of social collectives who performed a functional service out of a sense of normative obligation to promote and maintain the wider collective. The individual self can only be understood through its relational practice as part of a wider collective pattern. Thirdly, Mauss (1925) demonstrates how such collective patterns are constituted. Gifts are given but never completely separated from those who exchange them because the spirit of the gift creates a relational impetus for return. In the Thai Buddhist case, merit reciprocation for the gift generates a normative relationship or social bond, patterns of practice and consensus (be it fractured by status/power assertions) which determine the nature of society and governability. Finally, Mauss's work (1925) might be interpreted to emphasise that regimes of truth, dialectics of control or dominant actant networks are not therefore only instrumental agglomerations of contingent and pancratic practices (such as is often emphasised in use of Giddens, Foucault and Latour), but are also constructed through collective normative motivation and value consensus. As an analytical framework for Thai company reports, Mauss's (1925) theorisation is a pertinent example of the way in which a theory of relational practice might operate.

Although Mauss's spirit of the gift, when contextualised in Thai terms of the gift of mindfulness, relief of suffering (dukkha) and creation of socio-economic cohesion, is in part Buddhist in character, a Buddhist relational theory of practice would however further develop Mauss's functional interpretation (Mauss, 1925). For Mauss (1925), the individual self or agent in practice remains a function of the wider collective. Other social theorists have sought to elide further this binary dichotomy between individual self/agent and collective structures in different ways. Giddens (1984) in structuration theory has sought to break down this binary dichotomy through premising internalised virtual structures within the self which find recursive expression and modification in later practice. Latour (2005) has sought to 'localise the global' by emphasising the concatenous association and movement between transformative mediators/actants (human and non-human) acting in networks which create the constant translation of actions into different forms in a continual re-assembling of the collective. For Latour (2005, pp. 205-14), the individual actant is an assemblage of 'plug-ins' swarming in from other agencies and loci in the network. The base of Foucault's thought in Nietzsche $(1996,1994)$ also directed him away from allocating agency to an individual self (Foucault, 1977b, p. 142). Nietzsche $(1996,1994)$ rejected the existence of a metaphysical self and argued that what humans experience as their self is an unstable series of experiences/'under-souls' which present the illusion of a unitary, diachronic and continuous self. Whereas Nietzsche however perceived that constructing a self from its various 'under-souls' was essential for normative agency, Foucault's focus on formations of discursive practice de-recognises the agency of the metaphysical or individual self. In these different forms and degrees, later social theorists have sought to elide the dichotomy between individual and collective structural agency and have revised Mauss's (1925) functional view of the agency of the individual self as a member of the wider collective.

A Buddhist theory of relational practice would also challenge the premise that there is any permanent self and hence meaningful division between the self and collective. In the Anattalakkhana Sutta (Bodhi, 2000b, 22: 59, 901-02) the Buddha teaches the doctrines of impermanence (anicca) and not-self (anatta), namely that no permanent or metaphysical self exists or can be constituted by the five khandha or bundles/divisions that are seen to make up an individual (see Section 4.1). Clinging to belief in the permanence of the self is a primary cause of suffering (dukkha) because experience is the result of dynamic flows or patterns of impersonal external-internal factors which cannot be reified or bounded into a permanent self. The self can only be recognised as an imperfectly-coalescing, impermanent entity (literally a series of bundles or khandha) as part of a stream of ever-changing, inter-conditioning and ephemeral relations in life, and from life to life (Harvey, 1990, pp. 52-54). Buddhist relational practice in Thai annual reports is concerned with developing a mindfulness which transcends a unitary or isolatable perception of the self or collective self and perceives flows or patterns of relational practice in its place. It is this realisation of not-self or self-lessness and being constituent parts of wider patterns or flows of relational practice from which the agential values of Thai corporate social and environmental consciousness emerge. The gift of mindfulness in commercial practice (see Section 4.1) or corporate charitable donations (see Section 4.2) are aspirations towards realisation of the concept of not-self. Those with this aspiration seek to appreciate the impermanence of their identity as physically separate entities with human emotions/thoughts and realise that they only form parts or have meaning as parts of wider patterns of relational practice. In general parallel with Foucault's (1977b) de-recognition of the metaphysical and subjection of the individual self in genealogical formations, or Latour's (2005) actant who/which is an assemblage of 'plug-ins' swarming in from other agencies and loci in a network, and to a lesser degree Giddens's (1984) or Stones's (2005, pp. 109115) agent who is bound up in 'independent' and 'irresistible' causal forces in position-practice relations, a Buddhist relational theory of practice would premise a non-metaphysical and impermanent self whose agency is assembled and at best temporary because in reality it only forms parts and has agency as parts of wider flows and patterns of practice.

In contrast to Giddens, Latour and Foucault, however, it is the drive of this 'self' to mindfulness of its non-metaphysical and impermanent status as self-less parts in wider patterns, which is the fount of the normative motivation that Giddens's or Stones' structuration, Latour's network methodology and Foucault's genealogy seem to marginalise. The logic of agency in patterns of relational practice which is the basis of a Buddhist theory of relational practice differs from Giddens's (1984) or Stones's (2005) structuration, Latour's (2005) actor-networks, and Foucault's genealogies of relational practice (Foucault, $1977 \mathrm{a}, 1981$ ) in terms of its revision of their primary emphasis on instrumentality, determinism and, in Foucault's and to a lesser extent Giddens' case, pancratism. While Buddhist Conditioned Arising of the divisions (khandha) of the self towards 
mindfulness through practice bears some similarity to Giddens's (1984) or Stones's (2005) structuration, ultimately Buddhist 'self' and its agency are the result of merely temporarily aggregated bundles of attributes in wider flows and patterns of relational practice. The drive of this 'self to mindful understanding of its non-metaphysical and impermanent self-less parts in such wider patterns is the source of normative motivation in contrast to the instrumentalist emphasis in much structuration analysis which mostly defines normative motivation in terms of following dispositional 'norms' or conjunctural 'legitimation', while highlighting mainly pancratic purposes in terms of 'dialectics of control'. Moreover, as Thai annual reports also demonstrate, it is the driving force of the normative value of mindfulness and the moral consensus which it generates that in substantial degree interrelate the different methodological levels/brackets of social analysis proposed in structuration theory. Similarly, although Latour's actor-network theory (2005, pp. 183-90) effectively challenges the established 'sociology of the social' as well as 'panoramas' that mis-project local interpretation as a

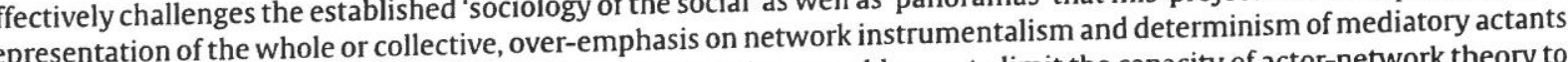
by 'plug-ins' swarming in from actants' networks of associations would seem to limit the capacity of actor-network theory to generate critical accounts of networks in terms of normative challenge to the limits of their knowledge and domination. A Buddhist theory of relational practice would emphasise that a normative flow of discriminative consciousness (vinnana) is generated recursively by every action and provides a creative force which allows the different khandha of the self (viz. Latour's 'plug-ins') to realise mindfulness and hence pursue normative improvement. It is not only the instrumentality of accounting practice and its determination of accounting actants which are important, but also the changing flow of pres which that instrumentality and determination convey. In terms of Foucault's pancratism, Foucault (1977b, 1981 ) avoided Nietzsche's dilemma on the normative agency of the metaphysical or individual self by drawing on Nietzsche $(1996,1994)$ for a genealogical methodology to concentrate on the emergence and re-invention of cultural phenomena from the viewpoint of power, reducing normative motivation to a mask for domination (Merquior, 1985, p. 101). In contrast to Nietzsche and Foucault, a Buddhist theory of relational practice premises that abandoning belief in the metaphysical self does not negate either the ability or need respectively for normative motivation. Indeed, a drive to abandon belief in the self serves to enhance normative agency because an appreciation that the self is an impermanent entity, which stimulates suffering/dukkha, thereby motivates an understanding of self-less practice to the normative benefit of all as reflected in Thai company reports. While it is possible on the one hand to agree with Foucault on the relativisation of normative practice in relation to power configurations (for example, normative gifting can be conditioned by the power status of Thai economic , the other hand to propose that power pervades social relations as their defining characteristic is quite different. A Buddhist relational theory of practice avoids Foucault's reductionist pancratism by revising the limiting perspective of accounting as primarily an instrument of power production, coercion and/or self-subjection, and recognising that accounting practice is driven by a range of forces, including normative motivation.

In sum, running through the critical accounting literature, at times stated and at other times under-stated or unstated, is a ciology of relational practice which emphasises in different ways that relational practice, and (as argued in this paper) dynamic and unfolding relational patterns of practice determine the nature of accounting. The generic limitation which arises across such different theories of relational practice, particularly those based on Giddens, Foucault and Latour, is how such patterns might be over-stated as contingent accumulations, instrumental networks or pancratic formations of evolving practice, rather than driven by normative judgement and value consensus which also translate into material and discursive patterns of governability. By critiquing Mauss (1925), this paper has sought to elaborate a theory of Buddhist relational practice in the Thai context and thereby to address the importance of normative values in building discursive and material patterns of governability through relational practice. Ultimately in the search for contextualised accounting (Hopwood, 1983), a Buddhist theorisation of practice would emphasise what might be further applied in the critical accounting literature, namely that accounting might be more fully contextualised by highlighting the agency that is generated, not by individuals or collective organisations/structures, but by the dynamics of relational practice and the normative patterns of practice of which individuals and organisations are parts.

\section{Acknowledgements}

The authors are grateful to the companies referenced for permission to reproduce photographs from their annual reports. We are also grateful to the anonymous reviewers and editor Professor Paolo Quattrone for their comments in revising the paper for publication.

\section{References:}

\section{Primary Sources:}

Banking: Annual reports: 2003, 2005 (2 companies), 2006, 2007, 2008, 2013.

Construction: Annual report: 2007.

Distribution services: Annual report: 2007.

Energy: Annual reports: 2004, 2006, 2008, 2011, 2013.

Energy: Sustainability reports: 2008, 2010-11.

Energy: Promotion CD: 2010.

Equipment manufacturing: Annual report: 2008. 
Financial services: Annual reports: 2004, 2006 (4 companies), 2007 (2 companies), 2008 (2 companies).

Gas and petroleum: Annual reports: 2004, 2006, 2008 (2 companies), 2010.

Hospitality: Annual reports: 2006, 2007, 2010-11.

Hospitality: Brand credo: 2010-11.

Hospitality: Company profile: 2010, Brochure, 2010.

Marine services: Annual reports: 2006, 2012, 2013, 2014

Media: Annual report: 2006.

Mining: Annual reports: 2007 (2 companies), 2008

Plastics and chemicals: Annual reports: 1998, 2006, 2008, 2010.

Publishing: Annual reports: 2006, 2007, 2008, 2014.

Steel Industry: Annual report: 2006.

Telecommunication: Annual reports: 2006 (2 companies), 2007, 2010.

Textile: Annual reports: 2006 ( 3 companies), 2007 (4 companies), 2008 (2 companies), 2014.

Transport: Annual reports: 1998-2014.

Transport: Sustainable development report: 2014

\section{Secondary Books/articles:}

Aho, J. A. (1985). Rhetoric and the invention of double-entry bookkeeping. Rhetorica 21-43. [Winter].

A ho, J. A. (2005). Confession and bookkeeping: The religious, moral and rhetorical roots of modern accounting. New York: State University of New York Press.

Ahrens, T., \& Chapman, C. S. (2002). The structuration of legitimate performance measures and management: Day-to-day contests of accountability in a UK restaurant chain. Management Accounting Research, 13(2), 151-171.

Ahrens, T., \& Chapman, C. S. (2004). Accounting for flexibility and efficiency: A field study of management control systems in a restaurant chain. Contemporary Accounting Research, 21(2), 271-301.

Ahrens, T., \& Chapman, C. S. (2005). Accounting and the crafting of strategy: A practice-based view. In C. S. Chapman (Ed.), Management accounting and strategy (pp. 106-124). Oxford: Oxford University Press.

Ahrens, T., \& Chapman, C. S. (2007). Management accounting as p ractice. Accounting, Organizations and Society, 32, 1-27.

Anderson, P. (1976). The antimonies of Antonio Gramsci. New Left Review, 100, 5-81.

Baker, C., \& Phongpaichit, P. (2005). A history of Thailand. Cambridge: Cambridge University Press.

Benschop, Y., \& Meihuizen, H. E. (2002). Keeping up gendered appearances: Representations of gender in financial reports. Accounting, Organizations and Society, 27(7), 611-636.

Bergsteiner, H., \& Dharmpiya, P. (2016). The sufficiency economy philosophy process. In G. C. Avery, \& H. Bergsteiner (Eds.), Sufficiency thinking: Thailand's gift
to an unsustainable world (pp. 32-52). to an unsustainable world (pp. 32-52). Sydney and London: Allen and Unwin.

Bernardi, R. A., Bean, D. F., \& Weippert, K. M. (2002). Signalling gender diversity through annual report pictures: A research note on image management. Accounting Auditing and Accountability Journal, 15(4), 609-616.

Blau, P. M. (1967). Exchange and power in social life. New York: John Wiley.

Bodhi, B. (Ed.). (2000a). A comprehensive manual of Abhidhamma: The Abhidhammattha Sangha of Acariya Anuruddha. Seattle: BPS Pariyatti Editions.

Bodhi, B. (Ed.), (2000b). The Connected Discourses of the Buddha: A translation of the Samyutta Nikaya. Boston: Wisdom.

Boggs, C. (1978). Gramsci's Marxism. London: Pluto.

Boland, R. J. (1993). Accounting and the interpretative act. Accounting, Organizations and Society, 18(2/3), 125-146.

Boland, R. J. (1996). Why shared meanings have no place in structuration theory. Accounting, Organizations and Society, 21(7/8), 691-697.

Bowrie, C. (1998). The alchemy of charity: Of class and Buddhism in northern Thailand. American Anthropologist, 100(2), 469-481.

Briers, M., \& Chua, W. F. (2001). The role of actor-networks and boundary objects in management accounting change: A field-study of implementation of activity-based costing. Accounting, Organizations and Society, 26(3), 237-269.

Broomfield, B. P., Cooper, D., \& Rea, D. (1992). Machines and manoeuvres: Responsibility accounting and the construction of hospital information systems. Accounting, Management and Information Technology, 2(4), 197-219.

Brown, J., Dillard, J., \& Hopper, T. (2015). Accounting, accountants and accountability regimes in pluralistic societies: Taking multiple perspectives seriously. Accounting, Auditing and Accountability Journal, 20(5), 626-650.

Buhr, N. (2002). A structuration view on the initiation of environmental reports. Critical Perspectives on Accounting, 13(1), 17-38.

Capps, T., Hopper, T., Mouritsen, J., Cooper, D., \& Lowe, T. (1989). Accounting in the production and reproduction of culture. In W. F. Chua, E. A. Lowe, \& A. G. Puxty (Eds.), Critical perspectives in management control (pp. 217-243). London: Macmillan. Carmona, S., Ezzamel, M., \& Gutierrez, F. (1997). Control and cost accounting practices in the Spanish Royal Tobacco Factory. Accounting, Organizations and
Society, 22(5), 411-446.

Carmona, S., Ezzamel, M., \& Gutierrez, F. (2002). The relationship between accounting and spatial practices in the factory. Accounting, Organizations and 239-274. Christensen, M., \& Skaerbaek, P. (2010). Consultancy outputs and the purification of accounting technologies. Accounting, Organizations and Society, 35(5),
524-545.

Chua, W. F. (1995). Experts, networks and inscriptions in the fabrication of accounting images: A story of the representation of three public hospitals. Accounting, Organizations and Society, 20(2-3), 111-145.

Coad, A. F., \& Glyptis, L. G. (2014). Structuration: A position-practice perspective and an illustrative study. Critical Perspectives on Accounting, $25,142-161$. Coad, A. F., \& Herbert, I. P. (2009). Back to the future: New potential for structuration theory in management accounting research? Management Accounting
Research., 20(3), 177-192.

Coad, A. F., Jack, L., \& Kholief, A. (2015). Structuration theory: Reflections on its further potential for management accounting research. Qualitative Research in Accounting and Management, 12(2), 153-171.

Coad, A. F., Jack, L., \& Kholief, A. (2016). Strong structuration theory in accounting research. Accounting Auditing and Accountability Journal, 29(7), 1138-1144

Cohen, I. J. (1989). Structuration theory: Anthony Giddens and the constitution of social life. London: Macmillan.

Cohen, I. J. (1999). Theories of action and praxis. In B. S. Turner (Ed.), The Blackwell companion to social theory (pp. 73-111). Oxford: Blackwell.

Conrad, L. (2005). A structuration analysis of accounting systems and systems of accountability in the privatised gas industry. Critical Perspectives on Accounting, 16(1), 1-26.

Davison, J., \& Warren, S. (2009). Imag|in]ing accounting and accountability. Accounting. Auditing and Accountability Journal, $22(6), 845-857$. Davison, J. (2002). Communication and antithesis in corporate annual reports: A research note. Accounting, Auditing and Accountability Journal, 15(4),
594-608. Davison, J. (2004). Sacred vestiges in financial reporting: Mythical readings guided by Mircea Eliade. Accounting, Auditing and Accountability Journal, 17(3),
476-497.

Davison, J. (2007). Photographs and accountability: Cracking the codes of an NGO. Accounting, Auditing and Accountability Journal, 20(1), 133-158.

(6), 883-890. 
Enterprise resource planning systems, management control and the quest for integration. Accounting, Organizations and Society, 30(7-8), 691-733.

years of social and environmental accounting research within Critical Perspectives on Accounting: Hits, misses and ways forward. Critical Perspective on Accounting, 43, 65-87.

forward. Critical Perspective on Accound Press.

Dreyfus, H. L., \& Rabinow, P. (1982). Michel Foucault: Beyond structuralism and hermeneutics. Brighton. Harvester Pre

Durkheim, E. (1984). The division of labour in society. (1st ed 1893)) New York: Free Press. [(Trans.) W.D. Halls]. $281-317$.

Emirbayer, M. (1997). Manifesto for a relational theory of sociology. The American Journal

Englund, H. \& Gerdin, J. (2008). Structuration theo

Perspectives on Accounting, 19(8), 1122-1134. Englund, H., \& Gerdin. J. (2014). Structuration theory in accounting research: Applications and applicabitions and the future. Accounting, Organizations and Englund, H., Gerdin, J., \& Burns, J. (2011). 25 years of Giddens in accounting research: Achievements, Society, 36, 494-513.

Strong structuration theory and accounting information: An empirical study. Accounting. Auditing and Accountability journal, 29 (7). $1152-1176$

Foucault, M. (1965). Madness and civilisation. New York: Vintage.

Foucault, $\mathrm{M}$. (1975). The birth of the clinic: An archaeology of medical perception. New York: Vintage.

Foucault $M$. (1977). Discipline and punish: The birth of the prison. London: Allen Lane.

列

Foucault, M. (1977b). In D. F. Bouchard (Ed.), Language, counter-memory, practice: Selected essays and interviews, Ithactighton: Harvester.

Foucault, M. (1980). In C. Gordon (Ed.), Power and knowledge: Selected

Foucault, M. (1981). The history of sexuality. Harmondsworth: Penguin.

Gallhofer, S., \& Haslam, J. (2017). Some reflections

Critical Perspectives on Accounting[in press].

dersal for emancipatory practice: Accounting delineation and mobilisation Gallhofer, S., Haslam, J., \& Yonekura, A. (2015). Accounting as differentiated universal for emancipatory practice: Accounting

for emancipation(s) recognising democracy and difference. Accounting, Auditing and Accountabily Joument performance. Accounting, Organizations and

Gendron, Y., Cooper, D. J., \& Townley, B. (2007). The construction of auditing expertise in measuring government
Society, 32(1-2), 101-129.

Giddens, A. (1979). Central problems in social theory: Action, structure and contradiction in social analysis. Londor

Giddens, A. (1984). The constitution of society: Outline of the theory of structuration. Cambridge: Polity Press.

Giddens, A. (1991). Modernity and self-identity: Self and society in the late modern age. Cambridge: Polity Press.

Giddens, A. (1993). New rules of sociological methods: A positive critique of interpretative sociologies. Cambridge: Polity Press.

Goodwin-Raheja, G. (1988). The poison in the gift: Ritual, prestation and the dominant caste in a north Indian village. Chicago and London: Chicago U

Press.

Gramsci, A. (1971). In Q. Hoare, \& G. N. Smith (Eds.). Selections from the prison notebooks, (1st ed 1929-35)) Londor

Gramsci, A. (1977). In Q. Hoare (Ed.), Selections from political writings 1910-20, London: Lawrence and Wishart.

Graves, O. F., Flesher, D. L., \& Jordan, R. E. (1996). Pictures and the bottom line: The television epistemology or and Society, 21(1), 57-88.

Greene, S. L. W. (1999). Absolute dreams: Thai government under Rama VI, 1910-25. Bangkok: White Lotus.

Greene, S. L. W. (1999). Absolute dreams: Thai government under Rame

Gregory, C. (1982). Gifts and commodities. London: Academic Press.

Grey, C. (1994). Debating Foucault: A critical reply to Neimark. Critical Perspectives on Accounting, 5(1), 5-24.

Harris, E. P., Northcott, D., Elmassri, M. M., \& Huikku, J. (2016). Theor

Accounting, Auditing and Accountability Journal, 29(7), 1177-1203.

Harvey, P. (1990). An introduction to Buddhism: Teachings, history and practices. Cambar Eastern Quarterly, 2, 15-30.

Heine-Geldern, R. (1942). Conceptions of state and kingship in south-east Asia. Far Eastern Quarterly, 2, 15-30.

Hopwood, A. G. (1983). On trying to study accounting in the contexts in which it operates. Account

Horner, I. B. (1938). Trans.]. Vinaya pitaka (The book of the disciplines). London: Pali Text Society.

$105-136$.

( The West Point connection. Accounting, Organizations and Society, 13(1), 37-73.

Hoskin, K. W., \& Macve, R. H. (1988). The genesis of accountability: The West Point consect post completion auditing reports. Accounting and Business

Huikku, J., \& Lukka, K. (2016). Research, 46(3), 243-277.

IFRS. IFRS application around the world jurisdictional profile: Thailand. http://www.ifrs.org/Use-around-the-world/Documents/Jurisdiction-profiles/ Thand-IFRS-Profile.pdf/ (Accessed 1/12/15).

Thailand-IFRS-Profile.p

Jack, L., \& Kholeif, A. (2007). Introducing strong structuration theory for informing qualitative case studies in 225. research. Qualitative Research in Organisations and Management: An International Journal, $2(3), 208-225$.

Jack, L., \& Kholief, A. (2008). Enterprise,

Accounting Forum, 32(1), 30-45.

Jack, L. (2007). Accounting: Post-productivism and corporate power in UK food and agriculture. Crist in contemporary Thailand. In T. Ling (Ed.), Buddhist

Jackson, P. (1993). Re-interpreting the Traiphum Phra Ruang: Political functions of Buddhist syir trends in Southeast Asia (pp. 64-100).

Joll, J. (1977). Gramsci. Glasgow: Fontana.

Jones, T. C., \& Dugdale, D. (2002). The ABC bandwagon and the juggernaut of modernity. Accounting Organizations and Soctability Journal, 24(2), 161-193.

Justesen, L., \& Mouritsen, J. (2011). Effects of actor-network theory in accounting research. Accounting, Auditing and Accountabilty journaling: Thailand's gift

Kantabutra, S. \& Winit, W. (2016). The sufficiency economy in action at Nithi Foods. In

to an unsustainable world (pp. 181-197). Sydney and London: Allen and Unwin.

Kearins, K., \& Hooper, K. (2002). Genealogical method and analysis. Accounting. Auditing and Accountability journal,

King Bhumibol Adulyadej (2009). The story of Mahajanaka, (1st edition 1996)) Bangkok: Amarin Printing and Publishing.

Knights, D., \& Collison, D. (1987). Disciplining the shopfloor: A comparison of the disciplinary effects of managerial psychology Accounting, Organizations and Society, 12(5), 457-477.

Kuasirikun, N. (2011). The portrayal of gender in annual reports in Thailand. Critical Perspectives on Accounting, 22(1), 53-78. University Press.

Latour, B. (1987). Science in action: How to follow scientists and engineers through society. Cambric

Latour, B. (1996). On actor-network theory: A few clarifications. Soziale Welt, 47(4), 369-38

Latour, B. (1996). On actor-network theory: A few Clarifications. Harvard University Press.

Latour, B. (1999). Pandora's hope. Cambridge, Massachusetts. Harvard University Press.

Latour, B. (2005). Reassembling the social: An int, fuction to actor-network theory. Oxford: Oxford University Press.

Lawrence, S., Alam, M., Northcott, D., \& Lowe, T. (1997). Ac Auditing and Accountability Journal, 17(4), 721-747.

Leach, E. R. (1961). Rethinking anthropology. London: Athlone.

Levi-Strauss, C. (1969). The elementary structures of kinship. London: Eyre and Spottiswoode.

Llewellyn, S., \& Northcott, D. (2005). The average hospital accounting. Accounting, Organizations and Society, 30(6), 553-583.

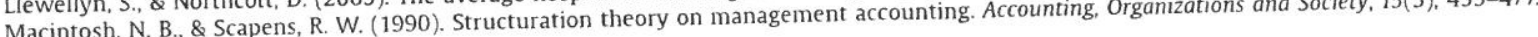


Macintosh, N. B., \& Scapens, R. W. (1991). Management accounting and control systems: A structuration theory analysis. Journal of Management Accounting Research, 3, 131-158.

Macintosh, N. B. (1990). Annual reports in an ideological role: A critical theory analysis. In D. J. Cooper, \& T. Hooper (Eds.), Critical accounts (pp. 153-172). London: Macmillan.

Macintosh, N. B. (1994). Management accounting and control systems: An organisational and behavioural approach. London. Chichester: John Wiley.

Macintosh, N. B. (1995). The ethics of profit manipulation: A dialectic of control analysis. Critical Perspectives on Accounting, 6, $289-315$.

Mackenzie, D. (2009). Making things the same: Gases, emission rights and the politics of carbon markets. Accounting, Organizations and Society, 34(3-4) 440-455.

Makrygiannakis, G., \& Jack, L. (2016). Understanding management accounting change using strong structuration frameworks. Accounting, Auditing and Accountability Journal, 29(7), 1234-1258.

Malinowski, B. (1922). Argonauts of the western Pacific: An account of native enterprise and adventure in the archipelagos of Melanesian New Guinea. London: Routledge and Kegan Paul.

Manson, S., McCarthney, S., \& Sherer, M. (2001). Audit automation as control within audit firms. Accounting. Auditing and Accountability Journal, 14(1), 109-130.

Marx, K. (1975a). Early writings: The economic and philosophical manuscripts. Harmondsworth: Penguin.

Marx, K. (1975b). Early writings: Concerning Feuerbach. Harmondsworth: Penguin.

Marx, K. (1975c). A contribution to the critique of Hegel's theory of right. In K. Marx (Ed.), Early writings (pp. 243-257). Harmondsworth: Penguin.

Mauss, M. (1925). Essai sur le don: Forme et raison de l'échange dans les sociétés archaïques. L'Année Sociologique (new series) 1, 1923-24. Librairie Felix Alcan, Paris, 1925, 30-186. First edition in English (1954) The gift: Forms and functions of exchange in archaic societies. London: Cohen and West.

Mauss, M. (1979). A category of the human mind, the notion of person, the notion of 'self. In M. Mauss (Ed.), Sociology and psychology: Essays, London: Routledge and Kegan Paul.

McFarland, G. B. (1954). Thai-English dictionary. Stanford: Stanford University Press.

Michaels, A. (1997). Gift and return gift, greeting and return greeting in India: On a consequential footnote by Marcel Mauss. Numen, 44(3), 242-269.

Miller, P., \& Napier, C. (1993). Genealogies of calculation. Accounting, Organizations and Society, 18(7/8), 631-647.

Miller, P., \& O'Leary, T. (1987). Accounting and the construction of the governable person. Accounting, Organizations and Society, 12(3), 235-265.

Miller, P., \& O'Leary, T. (2007). Mediating instruments and making markets: Capital budgeting, science and the economy. Accounting, Organizations and Society, 32(7-8), 701-734

Miller, P. (1990). On the interrelations between accounting and the state. Accounting, Organizations and Society, 15(4), 315-338.

Miller, P. (1991). Accounting innovation beyond the enterprise: Problematizing investment decisions and programming economic growth in the UK in the 1960. Accounting, Organizations and Society, 16(8), 733-762.

Moore, D. R. J.. \& McPhail, K. (2016). Strong structuration and carbon accounting: A position-practice perspective of policy development at the macro, industry and organisational levels. Accounting. Auditing and Accountability Journal, 29(7), 1204-1233.

Moore, D. R. J. (2011). Structuration theory: The contribution of Norman Macintosh and its application to emissions trading'. Critical Perspectives on Accounting, 22, 212-227.

Moore, D. R. J. (2013). Sustainability, institutionalisation and the duality of structure contradiction and unintended consequences in the political context of an Australian water business. Management Accounting Research, 24(4), 366-386.

Mouritsen, J., Hansen, A., \& Hansen, C. O. (2009). Short and long term translations: Management accounting calculations and innovation management Accounting, Organizations and Society, 34(6-7), 738-754.

Nietzsche, F. (1994). On the genealogy of morality, (1st ed 1887)) Cambridge: Cambridge University Press.

Nietzsche, F. (1996). Beyond good and evil. New York: Viking Press.

Ohnuma, R. (2005). Gift. In D. S. Lopez (Ed.), Critical terms for the study of Buddhism (pp. 103-123). Chicago: Chicago University Press.

Parry, J., \& Bloch, M. (1989). Money and the morality of exchange. Cambridge: Cambridge University Press.

Parry, J. (1980). Ghosts: Greed and sin: The occupational identity of the Benares funeral priests. Man (new series), 15, 88-111.

Parry, J. (1986). The gift, the Indian gift and the 'Indian gift'. Man (new series), 21(3), 453-473.

Poster, M. (1984). Foucault, Marxism and history: Mode of production versus mode of information. Cambridge: Polity Press.

Power, M. (1996). Making things auditable. Accounting, Organizations and Society, 21(2-3), 289-315.

Preston, A. M., Cooper, D. J., \& Coombs, R. W. (1992). Fabricating budgets: A study of the production of management budgeting in the National Health Service Accounting, Organisations and Society, 17(6), 561-593.

Preston, A. M., Wright, C., \& Young, J. (1996). Imag(in)ing annual reports. Accounting, Organizations and Society, 21(1), $113-137$.

Quattrone, P. (2004). Accounting for God: Accounting and accountability practices in the Society of Jesus (Italy 16th-17th centuries). Accounting, Organizations and Society, 29(7), 647-683.

Quattrone, P. (2009). Books to be practiced: Memory, the power of the visual, and the success of accounting. Accounting, Organizations and Society, 34, 85-118.

Ransome, P. (1992). Antonio Gramsci: A new introduction. Hemel Hempstead: Harvester Wheatsheaf.

Reynolds, F. E., \& Reynolds, M. (1982). The three worlds according to King Ruang: A Buddhist cosmology. Berkley Buddhist Series, Berkeley: University of California.

Reynolds, C. J. (1976). Buddhist cosmology in Thai history with special reference to 19th-century culture change. Journal of Asian Studies, 35(1), 203-220.

Reynolds, F. E. (1978a). Buddhism as universal religion and as civic religion: Some observations on a recent tour of Buddhist centres in central Thailand. In B. L. Smith (Ed.), Religion and legitimation of power in Thailand, Laos and Burma (pp. 194-203). Chamnersburg: Anima Books.

Reynolds, F. E. (1978b). Sacral kingship and national development: The case of Thailand. In B. L. Smith (Ed.), Religion and legitimation of power in Thailand, Laos and Burma (pp. 100-110). Chamnersburg: Anima Books.

Rhys-Davids, C. A. F., \& Woodward, F. L. (1917-30). [Trans.] Samyutta nikaya (The book of kindred sayings), 5 vols, London: Pali Text Society.

Rhys-Davids, T. W., \& Rhys-Davids, C. A. F. (1977). [Trans.] Digha nikaya (Dialogues of the Buddha), 3 vols, London: Pali Text Society.

Rhys-Davids, T. W., \& Stede, W., (Eds.) (1921-25). The Pali Text Society's Pali-English dictionary. Chipstead: Pali Text Society.

Roberts, J., \& Scapens, R. (1985). Accounting systems and systems of accounting - understanding accounting practices in their organisational contexts. Accounting, Organizations and Society, 10(4), 443-456.

Roberts, J. (1990). Strategy and accounting in a UK conglomerate. Accounting, Organizations and Society, 15, 107-126

Robson, K. (1991). On arenas of accounting change: The process of translation. Accounting, Organizations and Society, 16(5-6), 547-570.

Robson, K. (1992). Accounting numbers as 'inscription': Action at a distance and the development of accounting. Accounting, Organizations and Society, 17(7), $685-708$.

Rungruang, P., \& Ractham, V. V. (2016). Siam Cement Group as a sustainable enterprise. In G. C. Avery, \& H. Bergsteiner (Eds.), Sufficiency thinking: Thailand's gift to an unsustainable world (pp. 198-215). Sydney and London: Allen and Unwin.

Sahlins (1963). 'Poor man, rich man, big-man, chief: Political types in Melanesia and Polynesia. Comparative Studies in Society and History, 5(3), $285-303$.

Sahlins, M. (1972). Stone age economics. Chicago: Aldine.

Said, E. (1990). Orientalism. London: Penguin.

Schatzki, T. R. (2002). The site of the social: A philosophical account of the constitution of social life and change. University Park, PA: Pennsylvania State University Press.

Scheytt, T., Soin, K., \& Metz, T. (2003). Exploring notions of control across cultures: A narrative approach. European Accounting Review, 12(3), 515-547. 
Schrauwers, A. (2004). $\mathrm{H}(\mathrm{h})$ ouses, E(e)states and class: On the importance of capitals in central Sulawesi. Bijdragen Tot De Taal-, Land- En Volkenkunde, 160

(1), 72-94.

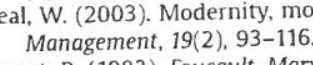

Smart, B. (1983). Foucault Marxism and critique. London: Routledge and Kegan Paul.

Smart, B. (1986). The politics of truth and the problem of hegemony. In D. C. Hoy (Ed.), Foucault: A critical reader (pp. 157-173). Oxford: Blackwell.

Smart B (1988). Michel Foucault. London: Routledge.

Stones, R. (2005) Structuration theory. Basingstoke: Palgrave Macmillan.

. Structuration theory

Thomas, N. (1991). Entangled objects: Exchange, material culture and colonialism in the Pacific Contradictions at General Motors 1917-76. Accounting, Organisations and Tinker, T., \& Neimark, M.

Society, 12(1), 77-88.

Tollington, T. (2006). U.K. Goodwill and intangible assets structuration: The FRS 10 rule creation cycle. Critical Perspectives control changes and performance in a Ghanaian Uddin, S., \& Tsamenyi, M. (2005). Public sector reforms and the public interal, 18(5), 648-674.

state-owned enterprise. Accounting, Auditing and Accountability Journal, 18(5), 648-674. Walsh, E. J., \& St

783-800.

(1) The paradox of keeping-while-giving. Berkeley: University of California Press.

Weiner, A. (1992). 